\title{
Review \\ Reconstitution and Transmission of Gut Microbiomes and Their Genes between Generations
}

\author{
Eugene Rosenberg * and Ilana Zilber-Rosenberg
}

Citation: Rosenberg, E.;

Zilber-Rosenberg, I. Reconstitution

and Transmission of Gut

Microbiomes and Their Genes

between Generations. Microorganisms

2022, 10, 70. https://doi.org/

10.3390/microorganisms10010070

Academic Editor:

Charalambos Billinis

Received: 30 November 2021

Accepted: 28 December 2021

Published: 30 December 2021

Publisher's Note: MDPI stays neutral with regard to jurisdictional claims in published maps and institutional affiliations.

Copyright: (c) 2021 by the authors. Licensee MDPI, Basel, Switzerland. This article is an open access article distributed under the terms and conditions of the Creative Commons Attribution (CC BY) license (https:// creativecommons.org/licenses/by/ $4.0 /)$.

\author{
Department of Molecular Microbiology and Biotechnology, Tel Aviv University, Tel Aviv-Yafo 6997801, Israel; \\ ilany43@gmail.com \\ * Correspondence: eros@tauex.tau.ac.il
}

\begin{abstract}
Microbiomes are transmitted between generations by a variety of different vertical and/or horizontal modes, including vegetative reproduction (vertical), via female germ cells (vertical), coprophagy and regurgitation (vertical and horizontal), physical contact starting at birth (vertical and horizontal), breast-feeding (vertical), and via the environment (horizontal). Analyses of vertical transmission can result in false negatives (failure to detect rare microbes) and false positives (strain variants). In humans, offspring receive most of their initial gut microbiota vertically from mothers during birth, via breast-feeding and close contact. Horizontal transmission is common in marine organisms and involves selectivity in determining which environmental microbes can colonize the organism's microbiome. The following arguments are put forth concerning accurate microbial transmission: First, the transmission may be of functions, not necessarily of species; second, horizontal transmission may be as accurate as vertical transmission; third, detection techniques may fail to detect rare microbes; lastly, microbiomes develop and reach maturity with their hosts. In spite of the great variation in means of transmission discussed in this paper, microbiomes and their functions are transferred from one generation of holobionts to the next with fidelity. This provides a strong basis for each holobiont to be considered a unique biological entity and a level of selection in evolution, largely maintaining the uniqueness of the entity and conserving the species from one generation to the next.
\end{abstract}

Keywords: microbiome; holobiont; hologenome; microbiota transmission; gene/function transmission; vertical transmission; horizontal transmission

\section{Introduction}

The hologenome concept of evolution [1,2] is based on four principles: (1) All animals and plants are holobionts, consisting of the host and diverse microbiota, including Bacteria, Archaea, eukaryotic microorganisms, and viruses. (2) Interactions between the host and its microbiota often affect the fitness of the holobiont in a beneficial manner, though negative interactions can also occur. (3) Microbiomes are transmitted between generations. (4) Alterations in either the host or the microbiome genomes (the hologenome) can lead to genetic variation and evolution. The microbiome genome is dynamic and changes more rapidly than the host genome. These principles stress the strong connection between the microbiome and the host in which a mutual adaptation has to evolve to achieve the robustness necessary for long-term survival [3,4]. Moreover, if these four principles are correct, then a holobiont with its hologenome is a level of selection in evolution [1,5]. In addition, and as a result, the approach to biological individuality and the concept of self has to undergo a change [6-8].

Out of the four principles, the main one that has been challenged is the transmission of microbiota between generations [9-11]. The critics argue that there is insufficient evidence to support the general claim that microbiomes are reconstructed each generation with fidelity. That seemed to us a good reason to focus on this intriguing subject and try to better understand its complexity. 
It should be mentioned that several recent reviews have been published on different aspects of microbiome transmission. These reviews discuss plant microbiomes [12-15], animal microbiomes [4,16-20], and human microbiomes [21-25]. This article is an updated opinion review that discusses plants and animals, including humans.

In a nutshell, this article critically examines the evidence, pros and cons, for transmission of microbiota and their genes between holobiont generations. However, there are some obstacles that lie ahead, the main ones being the diverse routes by which microbiota are vertically and horizontally transmitted between hosts [26,27] and the limits of detection of rare microbiota within holobionts [28-30]. Additionally, although the number of studies on the microbiota of animals and plants is rapidly expanding [21,31,32], there is still a paucity of species in which transmission of microbiomes have been studied in depth [33-35], which makes it challenging to generalize. However, we shall try to come to some general conclusions.

\section{Modes and Fidelity of Transmission}

As is well known, the gastrointestinal tract is sterile in the normal fetus up to the time of birth. During normal birth, however, the baby picks up microbes from the vagina and external genitalia of the mother and any other environmental source to which it is exposed.-Dwayne C. Savage [36]

Whereas animal and plant genomes are transmitted between generations by a wellestablished universal semi-conserved mechanism, microbiota and their genes are transmitted by a variety of different vertical, horizontal modes (Table 1), and as will be discussed later, also by mixed modes. Vertical transmission is defined as the movement of microbiota from parent to offspring without mixing with microbes in the environment, whereas horizontal transmission is defined as coming from the environment [5]. We shall first examine the phenomena of vertical and horizontal transmissions in different organisms and discuss the fidelity of the phenomena, then discuss aspects of quantitative assessment of transmission and finally we will derive some general conclusions from the data presented in the paper.

Table 1. Modes of transmission of microbiota.

\begin{tabular}{cc}
\hline Mode of Transmission & Examples \\
\hline Vegetative reproduction (vertical) & $\begin{array}{r}\text { Plants, worms, corals, sponges, sand dollars, bryozoans, } \\
\text { starfish, sea urchins, sea cucumbers }\end{array}$ \\
\hline $\begin{array}{c}\text { Female germ cells: eggs, embryos } \\
\text { and seeds (vertical) }\end{array}$ & $\begin{array}{c}\text { Mitochondria, chloroplasts, aphid/Buchnera, } \\
\text { Drosophila/Wolbachia, chicken embryo/microbiota, plant } \\
\text { seeds/microbiota }\end{array}$ \\
\hline $\begin{array}{c}\text { Coprophagy } \\
\text { (vertical \& horizontal) }\end{array}$ & $\begin{array}{c}\text { Insects, rodents, iguanas, rabbits, pigs, horses, elephants, } \\
\text { pandas, koalas, primates, termites }\end{array}$ \\
\hline Regurgitation of food (vertical) & Birds, beetles \\
\hline $\begin{array}{c}\text { Physical contact starting at birth } \\
\text { (vertical \& horizontal) }\end{array}$ & Most organisms \\
\hline Mother's milk (vertical) & Mammals \\
\hline Environmental (horizontal) & Squid/Vibrio fischeri, grasses/endophytes, fish/microbiota \\
\hline
\end{tabular}

For a holobiont to be considered a level of selection in evolution, a significant fraction of its microbiome must be transferred between generations [5,8]. The diverse modes of transmission by different animals and plants make it difficult to derive generalizations concerning the fidelity of transmission. However, what is clear is that, in general, a functional microbiome has to be reconstituted each generation, thereby achieving fitness of the holobiont throughout its life. This conclusion leads to a number of major questions regarding the mode of transmission of the microbiome: What fraction of the microbiome 
is transferred vertically and what fraction horizontally or mixed? Does it matter if the microbiome is reconstituted by vertical and/or horizontal transmission? How important is the transmission of specific taxa as opposed to transferring specific and necessary functions/genes of the microbiome to the next generation? This section examines the fidelity of transmission of the different modes.

\subsection{Vertical Transmission: Modes and Fidelity}

Accurate vertical transmission and co-evolution have been demonstrated in many biological systems, co-evolution being defined as the process in which two or more species reciprocally affect each other's evolution [37]. Funkhouser and Bordenstein [38] have argued that microbial maternal vertical transmission is widespread across animals. Vertical transmission is most important in assuring fidelity and accurate reconstructing of the next generation holobiont and hologenome.

\subsubsection{Vegetative Reproduction}

Vegetative reproduction is an asexual reproduction occurring when no embryo is produced. Many plants and some animals can propagate asexually from somatic cells [39-42]. As a result of this type of reproduction, the microbiome is transferred vertically to offspring as part of the separated tissue. The most obvious example is vegetative reproduction in plants. Diverse plants can multiply vegetatively by producing runners, rhizomes, or root sprouts [43]. Although temporarily connected to the parent, if the segments can live independently after separation, it results in vegetative propagation [44]. Vegetative reproduction also occurs in some simple animals. The animal is broken, into two or more pieces; each fragment can form a fully-grown new organism, identical to the parent. For example, fragmentation occurs in corals [45], worms [46], sea stars [47], and sponges [48]. Budding is another type of asexual propagation in animals, resulting from the outgrowth of a part of the body leading to a separation of the bud from the original organism and formation of two individuals, one larger than the other. Budding occurs in sponges [49], sand dollars [50], Hydra [51], echinoderms [52], and bryozoans [53].

\subsubsection{Cytoplasmic Inheritance, Germ Cells, and Fetuses}

Cytoplasmic inheritance, also referred to as extra nuclear inheritance, is transmission of genes that occur outside the nucleus. It is found in most eukaryotes and includes inheritance of mitochondria and chloroplasts, which can be considered "extreme symbionts" because though now considered organelles, they originated from alphaproteobacteria and cyanobacteria, respectively [54,55]. In general, all animals inherit their mitochondria only from their mother [56]. Maternal transmission of mitochondria is so precise that it can be used in tracing evolutionary lineages and population migrations [57]. Similarly, chloroplasts are maternally transmitted [58], with rare cases of paternal inheritance [59].

Vertical transmission from parent to offspring via oocytes occurs with several invertebrate endosymbionts, where the microorganisms are present in or on the reproductive cells. In the aphid-Buchnera symbiosis, for example, bacteria are intracellularly located in bacteriocytes and are transferred to and transmitted via the eggs [60-62]. Another well-studied example of vertical transmission via oocytes is in the Drosophila-Wolbachia endosymbiosis. Wolbachia is the most common endosymbiont in insects [63,64]. This endosymbiont is always present in female germ line stem cells, so that translocation of the symbiont is not necessary. It is well-established that endosymbionts in insects are vertically transmitted between generations with high fidelity and co-evolve with their hosts [65]. Some of these close associations between endosymbionts and their insect hosts are apparently evolutionarily stable for hundreds of millions of years [66,67], and during this long period a host-symbiont co-speciation has occurred [61]. Since these symbionts are unable to live outside of their host cells, it is unlikely that they are acquired from the environment, but rather, they are faithfully vertically transferred from mother to offspring [38]. In strictly 
vertically transmitted intracellular associations, mutation and genetic drift over millions of years has resulted in severe genome erosion of the symbiont [68].

In many corals, the endo-symbiotic algae, Symbiodinium, are transmitted directly from parent to offspring via eggs. This mechanism of symbiont transmission perpetuates Symbiodinium diversity found in the parent through multiple generations [69]. In some sponges, symbiotic bacteria penetrate into growing oocytes by endocytosis [70]. Many insects such as fruit flies [71], stinkbugs [72], and other arthropods [73], transfer their microbiota from their gut to the eggs they lay.

Inside the shells of chicken eggs exist an abundant and highly diverse bacterial population, derived from the mother and associated with the developing chick fetus [74-76]. It appears that the chicken embryo obtains its intestinal microbiota from the egg white prior to hatching. Thus, microbiota is transmitted vertically from hen to offspring via eggs. Eggs of wild birds and lizards also contain in ovo microbial communities, presumably through the inoculation of egg yolk prior to shelling [77].

The presence of bacteria inside eggs raises the question of whether other animals also transfer microbiota directly to their fetuses prior to birth. In humans, it was accepted for more than a century, that the fetus matures in a bacteria-free environment prior to birth. However, several publications during the last ten years report the presence of bacteria in the human fetal environment including inside the placenta [78-83]. It has also been reported that calf fetuses are not sterile, but are spatially colonized before birth by a pioneer microbiome [84].

A number of scientists have challenged the prenatal microbiome hypothesis, identifying contamination as a major issue [85-88]. Furthermore, the fact that it is possible to generate germ-free mammals by Caesarean section suggests that the fetus must be sterile. A panel of microbiome experts, who have not been directly involved in the debate, were asked to discuss these issues and publish their thoughts on the controversy [89]. The following statement by Martin Blaser reflects the general conclusion of the panel: "Any claim that there is indeed an indigenous microbiota would need to be well-substantiated and unequivocal, since it would need to surmount both existing theory and logic. At this point, no finding has passed that threshold, in my opinion."

Plant seeds play an important role in the vertical transmission of bacteria and fungi between successive generations, thereby ensuring their presence in the next generation [90-92]. Seeds have the potential to remain in a dormant state for a considerable period of time until growth conditions become suitable for their germination and development into a new plant [93].

\subsubsection{Coprophagy}

Coprophagy is feces-eating behavior [94]. This mode of microbial transmission via feces consumption has been reported in a large number of animal species, including insects, rodents, piglets, foals, dogs, and nonhuman primates [95]. Coprophagy allows the young animals to obtain gut symbiotic microbes, which they require to digest complex polysaccharides, from their parents [95-97]. Koalas use a special adaptation of coprophagy [98,99]. For months, the joey relies entirely on the mothers' milk; subsequently, the mother produces a special type of feces (pap), which the joey consumes over several days. This process facilitates vertical transmission of microorganisms that are able to digest eucalyptus leaves. Other examples of direct transmission via feeding feces is observed in termites $[100,101]$, and some cockroach species [102,103], in addition to some insects that lay eggs in their feces that is consumed by the hatching offspring [104].

Coprophagy can bring about also a mixed mode of transmission (MMT, see further in this review), namely, not just strictly vertical, but also partially horizontal, as is common among some insects [105]. This takes place when the offspring consume feces from the ground, not directly from the parent. 


\subsubsection{Regurgitation of Food}

Many bird species regurgitate food into the mouths of their young, thereby ensuring a direct vertical mode of microbial transmission [106]. Regurgitation and ingestion of food by primates are behaviors that are pervasive in zoos, but have not been observed in animals in the wild $[107,108]$. Some beetles feed regurgitated food, and potentially also bacteria, to larvae throughout their development [109].

Just as mammals breastfeed their offspring, parent rock pigeons regurgitate pigeon milk from an enlarged part of their esophagus to feed the chicks, termed squabs [110]. However, unlike mammals, both male and female pigeons produce pigeon milk [111]. The relatively high percentage of shared bacterial species between squabs and their parents is a strong indication that the squabs obtain bacteria through regurgitation of parental milk [112,113].

\subsubsection{Physical Contact}

The mode of delivery in all animals shapes the acquisition and structure of the initial microbiome in newborns $[114,115]$. The newborn human gut is initially colonized via inoculation with maternal vaginal and fecal microbes, when the baby passes through the birth canal (vertical transmission). Direct vertical transmission during birth has been demonstrated in several animals, including bears [116], great apes [117], bats [118], mice [26], beetles [119], and fishes [120,121], in addition to humans [122-124]. Moreover, Li et al. [124] demonstrated that antibiotic administration to mothers during birth reduced considerably and changed the vertically transmitted species.

Cesarean section (CS) delivery is one of the strongest disrupting factors of the normal colonization process and has been reported as a risk factor for disorders in later life [125]. Human infants born by CS are colonized initially and primarily by skin microbiota $[126,127]$ Subsequent colonization occurs in humans by close physical contact of the offspring with parent, family, and community members [128]. Kissing, hugging, and touching result in the transfer of microbes [129]. Kort et al. [130] demonstrated that, in humans, an average 10-s open-mouth kiss transfers approximately 80 million bacteria. However, social transmission, between individuals, within herds and between populations, all being horizontal, also occurs in many animals [131], including non-human primates [132], herbivores [133], and birds [134].

In humans, an early discovered example of a microbe being transmitted from parent to offspring for many generations came from a detailed analysis of the sequence diversity of DNA isolated from specific strains of Helicobacter pylori, present in different geographic human populations $[135,136]$. H. pylori is acquired early in life from mothers and occasionally from family members $[137,138]$. The fact that a distinct strain-specific sequence remains for centuries in offspring of an individual that has migrated to a different geographical location, argues for accurate transmission. This has led to the use of $H$. pylori in discovering details of human migration at individual and population levels [139,140].

One way to assess whether microbes are influenced by the genetic composition of the host, and therefore conserved across generations, is by measuring heritability $\left(h^{2}\right)$-the proportion of phenotypic variance explained by genetic variance [141]. For example, recently it was reported that $97 \%$ of microbiome phenotypes in wild baboons were significantly heritable [142]. In humans, because the overall similarity of gut bacterial community composition between adult mono- and di-zygotic twin pairs is largely the same, it is reasonable to conclude that physical contact during and after birth has a greater influence as compared to genetic relatedness, in determining gut microbial composition [143,144]. Although it is not clear how much of the human gut microbiome is transferred from mother to infant, several groups of bacteria, such as specific strains of Bifidobacterium breve and Lactobacillus plantarum, were shown to be always present in the infant gut and their mothers' feces and milk [145-147], providing direct support for accurate vertical transmission of these strains. Strains from the classes Actinobacteria and Bacteroidia, which are essential components 
of the infant microbiome, have been shown to be vertically transmitted from mother to offspring and persist for at least 1 year after birth [148].

\subsubsection{Breastfeeding}

Breastfeeding is another important route of maternal vertical microbial transmission to offspring in mammals $[149,150]$. Breast milk from healthy human mothers contains ca. $10^{5}$ bacteria per $\mathrm{ml}$, composed of hundreds of species of commensal and mutualistic bacteria [151]. These bacteria are provided to the newborn infants' gastrointestinal tract during early and critical periods of development [152]. Analyses of the DNA of several bacterial strains isolated from mothers' milk demonstrated that they were identical to those found in the offspring [153]. Asnicar et al. [154] demonstrated that several specific strains (e.g., Bifidobacterium bifidum, Coprococcus comes and Ruminococcus bromii) were present in samples from the same mother-infant pair, while being clearly distinct from those carried by other pairs, which is indicative of vertical transmission.

One particular bacterial genus in breast milk that warrants special attention is Bifidobacterium. Members of this genus are uniquely genetically adapted to utilize glycans present in human milk as an energy source [155]. While this genus makes up only a small percentage of human milk bacteria, it dominates the gastrointestinal microbiome of breastfed infants [156], where it plays important roles in shaping the infant GI microbiome and programming health [157]. The clear demonstration that these beneficial bacteria co-evolved with humans can be perceived from their interaction with human milk oligosaccharides (HMOs). These HMOs, which are complex carbohydrates and uniquely abundant in breast milk, have evolved while supporting the assembly of a healthy gut microbiome in the human infant [158]. The HMOs do not provide energy to the infant; instead, they are used exclusively by the gut microbiota that have evolved specific enzymes that metabolize HMOs [159]. These data demonstrate a clear co-evolution of certain strains of bacteria with humans [37].

Fungi and viruses have also been detected in the breastmilk of healthy human mothers, as well as the milk of other animals [160-162]. A thorough review on milk microbiomes has recently been published by Oikonomou et al. [152].

The origin of human milk microbes is not clear [163]. One suggestion is that a preexisting mammary gland microbiome acts as the initial seed for the human milk microbiome [164]. Another possibility is that microbes access the mammary tissue in nonpregnant, non-lactating individuals because mammary glands are exposed to the environment via the nipple. In fact, bacterial DNA has been identified in non-lactating mammary tissue from women undergoing breast surgery [165]. The non-lactating mammary tissue of nonhuman primates has also been shown to contain bacterial DNA [166]. Thus, bacterial DNA may be present in the mammary gland prior to the onset of first lactation. These bacterial DNA profiles share some features with the human milk microbiome. Furthermore, it was possible to culture bacteria from breast tissue suggesting the presence of a viable mammary microbiome $[167,168]$. A third possible rout is suggested by studies demonstrating that bacteria consumed orally by lactating women or animals can subsequently be isolated from their milk [169], indicating that bacteria may also reach the mammary gland through an internal pathway. The proposed entero-mammary pathway involves immune cell-mediated bacterial translocation from the mother's gastrointestinal tract into the mammary gland $[170,171]$. Bacterial translocation increases toward the end of pregnancy, possibly acting as a second seeding event [172]. Once the milk starts to be produced in the breast, the composition of the microbiome appears to change, probably due to the introduction of different bacterial substrates and immune factors present in colostrum and milk.

\subsubsection{Vertical Transmission over Evolutionary Time-Scales}

Vertical transmission of bacteria over evolutionary time-scales was investigated by analyzing and comparing the $16 \mathrm{~S}$ rRNA gene sequences of bacteria present in the great apes, 
including humans $[173,174]$. Since the host species phylogenies based on the composition of these bacterial communities was parallel to the evolutionary relationships of their hosts, Ochman et al. [173] concluded that "over evolutionary timescales, the composition of the gut microbiota among great ape species is phylogenetically conserved and has diverged in a manner consistent with vertical inheritance". This conclusion was challenged by Moran and Sloan [9]. They correctly pointed out that vertical transmission of bacterial species, based on 16S rRNA gene sequences alone, cannot be used to prove co-evolution because it is possible, even likely, that over evolutionary timescales other strains of the same species (>97\% identity in 16S rRNA gene sequence) could have been acquired from the environment (horizontally).

To overcome the problem raised by Moran and Sloan [9], Sanders et al. [175] developed the beta-diversity clustering method, which distinguishes between shared evolutionary history and environmental filtering. Applying this method to the great ape data led to the conclusion that great apes acquire microbiota largely from the environment, but retain a significant proportion of vertically transmitted microbes over long timescales. When the method was applied to turtle ants, the data indicated that vertical transmission of the entire bacterial community played an important role in the evolution and maintenance of the turtle ant/microbiome association [175].

Moeller et al. [176] used a different approach to test the fidelity of microbiota transmission in great apes. They employed rapidly evolving gene sequences instead of stable $16 \mathrm{~S}$ rRNA genes, to analyze the fidelity of gut bacterial transmission in humans, wild chimpanzees, and wild bonobos. The analyses led to the conclusion that strains of the common gut bacteria, Bacteroidaceae and Bifidobacteriaceae, have been preserved within host lineages across hundreds of thousands of host generations. Since the divergence times of these co-speciation gut bacteria are congruent with those of hominids, it can be concluded that nuclear, mitochondrial, and gut bacterial genomes, i.e., hologenomes, diversified in concert during hominid evolution. Thus, though a predominant fraction of gut bacteria originates from the environment, a significant fraction has co-evolved for millions of years with hominids and participated in their adaptation and development [177]. Furthermore, Rampelli et al. [178] demonstrated that in the gut microbiota of Neanderthal occupational deposits, dating back 50 thousand years, many well-known beneficial gut commensals already populated the gut microbiome of Homos as far back as the last common ancestor between humans and Neanderthals.

\subsection{Horizontal Transmission}

Most symbiotic microorganisms, being part of a holobiont, are adapted to living within their host; moreover, some cannot replicate outside, which reflects their adaptation to specific niches in their hosts $[179,180]$. In humans and in mice, the two most abundant bacterial phyla are the Firmicutes and the Bacteroidetes, most of which do not grow outside of their host [181]. Adaptation to growth in their hosts is not only common in animals, but is also common in plants [182]. A consequence of this is that symbiotic microbes can generally outcompete environmental organisms for residence in their hosts.

Regardless of this competition mechanism, infection of holobionts by environmental non-pathogenic (also pathogenic, but they are not the subject of this article) microbes occurs all the time. However, in order for such environmental bacteria to persist and multiply in a host they have to be well adapted to the host or else the immune system and the resident microbiota will not enable their colonization, and second, they have also probably to participate in some way in the fitness of the holobiont or at least be commensal.

Just as there are multiple modes of vertical transmission, so can horizontal transmission be divided by the source of the acquired microbe, though it is more difficult to prove its origin. Offspring often acquire horizontally transmitted microbes not from a parent, but from a family member or any other organism in which they are in close contact with. For example, it has been reported that humans acquire microbes also from their pets [183,184]. Although in some cases horizontal transmission is apparently the main mode of transmis- 
sion, mostly it takes place together with vertical transmission (see discussion further in the paper, mixed mode).

One of the arguments against considering the holobiont with its hologenome as a level of selection in evolution is the pervasiveness of horizontal transmission, which is claimed to prevent reliable reconstitution of the microbiome between generations $[10,185,186]$. Douglas and Werren [10] have argued that host-symbiont partner fidelity is weak for many horizontally acquired symbioses. As examples, they note that gut microbiota in genetically defined strains of laboratory mice and Drosophila melanogaster varies among laboratories, even within one laboratory, over time [187-190]. In our opinion, these examples may indicate that the relative numbers of specific microbes in the microbiome can change as a function of environmental factors and when the frequency of a species or strain goes below a critical number it can no longer be detected, as will be discussed in Section 4 . An additional study of eight marine sponges, spanning two classes, casts doubt on the consistency and faithfulness of transmission of microbiomes between generations [11]. The data from the study suggest that siblings receive only a small set of identical symbionts and that the majority of these microbes originate from the seawater where they were probably selectively acquired by the adult parent before being vertically transmitted to offspring. The authors conclude that it is unlikely that microbiota have co-evolved with particular sponge species. However, the authors are aware of the finding that adult sponges have highly species-specific microbiomes [191] and suggest two possible explanations for the lack of vertical transmission of parental microbes to larvae. First, they suggest, as others do [192] that priority influences community, namely, only a small number of essential microbes need to be transferred vertically from parent in order to build eventually a functional adult microbiome and holobiont. Second, though sponges filter an enormous quantity of water with a vast numbers of microorganisms (mostly as food) they are able to recognize specific microorganisms via their innate immune system and specific molecular structures. Both these mechanisms point to the process of development of the mature microbiome that becomes species specific. Ramos et al. [193] discussing functional (not taxa) microbial composition across generations (see further in this article) also suggest that in humans vertically transmitted microbiota begin a predictable change of functions whose fitness depends on the arrival of additional bacteria.

Despite the evidence for weak vertical transmission and higher horizontal transmission in different organisms and systems, there exist examples of faithful reconstructions of a holobionts and hologenomes by horizontally transferred symbionts [194-200].

Probably the best-studied example of environmental transmission occurs in the squidVibrio fischeri symbiosis $[195,201]$. The female squid lays clutches of hundreds of fertilized eggs, which hatch almost synchronously at dusk. In parallel, adult squids release large amounts of $V$. fischeri into the water at dawn every day. The growing embryos develop an immature light organ that harbors pores leading to separate epithial-lined crypts. These crypts become colonized by the released $V$. fischeri from the surrounding water. Accurate transmission is ensured by the developing squid that provides a niche only for the $V$. fischer $i$ that emits light and is able to maintain a stable association. Thus, the squid microbiome is reconstituted every generation by a specific environmental transmission, though not necessarily from their specific parent.

Horizontal transmission in the marine environment is often mediated through a mucous interface and requires complex recognition mechanisms, most often involving sugar-lectin interactions and cellular surface structures that select specific symbionts from the environment and avoid pathogen invasions [202].

Horizontal transmission among many land animals, occurring via consumption of plant material, is probably part of the natural transmission process necessary for passage of microorganisms, that breakdown plant material, to offspring. Studies have demonstrated that bacteria associated with raw-eaten leafy green vegetables, or even with processed foods, are ingested by their consumers, in other words they are horizontally transferred to herbivore and omnivore animals, including to humans [203]. 
An interesting recent publication describes horizontal transmission of gut microbiota between two different animal species living in the Tibetan Plateau, the pika (a small harelike mammal) and the yak [204]. The pika and yak have been sharing the same habitats, and consuming similar foods for more than a million years and therefore are considered competitors. Surprisingly, it was observed that when the yak population increased, causing overgrazing, the population size of pikas also increased. When trying to discover the underlying mechanism for this unexpected finding and examining the microbiomes of sympatric and allopatric pikas and yaks, the researchers discovered that sympatry increased both gut microbial diversity and similarity between pikas and yaks. In sympatry, pikas acquired 2692 OTUs from yaks, and yaks obtained 453 OTUs from pikas. In the pikas, these horizontally transmitted bacteria enhanced the enrichment of pathways related to prebiotics and immunity. In yaks, the horizontally transmitted bacteria enhanced pathways related to hepato-protection, xenobiotic biodegradation, and detoxification. Thus, pikas and yaks may not be chiefly competitors, but rather their relationship may be characterized by reciprocity through the horizontal transmission of gut microbiota. The mode of transmission probably occurs by pikas eating the feces of yaks [205], and yaks acquiring pika excretions in the soil [206].

Horizontal transmission has been shown to exist in many additional animals and plants. Studies in both humans [207] and non-human primates [208] provide strong evidence for the contribution of horizontal transmission to microbiome assembly. Tung et al. [209] showed that social networks and social interactions in wild baboons, could predict microbiome structure, even after controlling for shared environment, diet, and relatedness. In another study, it was reported that in several different surveyed non-human primate species microbiomes varied with host species, but importantly also by social groups within species [210]. Other examples of horizontal transmission include plant to other plants via fungal propagules (a vegetative structure that can become detached from a plant) in grasses [196], via the nesting environment in wild birds [211], and from the surrounding water in fish [212,213]. Horizontal transmission of endosymbionts of insects such as Wolbachia, Ricketssia, Cardinium and the parasite of a leafhopper via plants has also been described [214].

Recently, it was reported that microbes could be transmitted not only from plants to animals, but also from animals to plants. Lettuce grown in soil containing cattle manure, acquired in their leaves manure-borne microbes that include antibiotic resistance genes, which may assist in protection against infection [215]. Moreover, antibiotic resistance genes, acquired from poultry litter was present in the roots of lettuce [216].

Roughgarden [217] has presented a mathematical model to examine how holobiont selection might operate and to assess its plausibility as an evolutionary force. In one variant of the model, offspring obtain microbiomes from their parents directly (vertical transmission). In the complimentary variant, microbiomes of offspring are assembled from source pools containing combined microbiomes existing in the near environment from all parents, as in the squid/Vibrio system (horizontal transmission). According to both variants of the model, holobiont selection causes evolutionary change in holobiont traits. Therefore, holobiont selection is plausibly an effective evolutionary force with either mode of microbiome transmission.

What are the advantages of horizontal transmission of microbiota? Since some of the microbiome members are not vertically transmitted in a reliable way [218], strong natural selection would favor hosts that can seize useful symbionts from the local environment $[219,220]$. Another advantage of acquiring microbes from the environment is the possibility of genetic variation and evolution of holobionts by the occasional acquisition of a novel beneficial strain [221]. The presence of an environmental component implies that offspring can be colonized by beneficial symbionts as well as environmental bacteria that can harm the host $[105,222]$. Accordingly, the establishment of a healthy microbiome will depend on the ability of the holobiont to acquire beneficial bacteria and exclude pathogens [223]. During microbiota transmission (whether vertical or horizontal), selection 
by the host and/or by components of the microbiome, is a key process in establishing and maintaining a holobiont microbial community that is fit for the specific host in its environment [224].

\subsection{Mixed Vertical and Horizontal Transmission}

Symbiont transmission modes are best conceptualized on a spectrum between strict vertical and strict horizontal transmission. In between these extreme modes, exist the mixed mode of transmission (MMT), involving vertically and horizontally transmissions of the same microbe or microbiome or host switching of the same microbe [225]. Ebert [225] claimed that MMT is the dominant mode of transmission in the animal and plant worlds. A systematic review and meta-analysis of modes of microbiota transmission performed by Russell [226] showed that out of a total of 528 analyzed symbioses, 43\% were strictly vertically transmitted, $21 \%$ were strictly horizontally transmitted, and $36 \%$ exhibited some form of MMT, which he predicted to be generally underestimated because of relatively fewer data. In general, Russell concluded that external modes of vertical transmission (e.g. secretions), as opposed to internal modes (e.g., intracellular), predisposed holobionts to mixed modes of transmission. In addition, Russell observed that a higher frequency of vertical transmission existed on land and a higher frequency of horizontal transmission existed in aquatic environments [226,227]. The observation of horizontal transmission being more abundant in the marine than in terrestrial environment could arise from the simple fact that water is a conducive medium in which desiccation and osmolarity do not represent a problem, thus encouraging horizontal transmission and host to-host transfer events [4]. For example, in the sponge, Plakina cyanorosea, harboring a relatively low microbial abundance, transmission of its microbiome relies primarily, but not exclusively, on horizontal transmission [220]. However, there is now also evidence for maternal vertical inheritance in deep-sea animals as well [220,228,229], indicating a mixed vertical and horizontal transmission. In chemosynthetic symbionts in deep-sea mussels both horizontal [230] and vertical transmission [231] have been reported. Transmission of chemosynthetic symbionts in these organisms is an important determinant of population structure and genome evolution [230]. It seems that stochastic effects on the colonization of horizontally transmitted bacteria may manifest themselves also on land in differences of microbiota strain composition among hosts, as was reported for the nematode Caenorhabditis elegans [232].

Moeller et al. [26] working with two strains of mice from the wild, that were bred for up to 11 generations in the lab, demonstrated an individual and population level transmission which was predominantly vertical, but also environmental, namely a mixed transfer of microbes. They also observed that the mode of transmission tends to be dependent on bacterial genera. In addition, aerobic bacteria tended to be transmitted horizontally and anaerobic bacteria-vertically. Other examples of mixed transmission of microbiomes were observed in great apes, as discussed above [175], in ruminants [233,234], in mammalian herbivores [235] in insects [199] and in corals [69].

\section{The Core Microbiome and Transmission of Functions and Genes}

The most accepted definition of a core human microbiome is a group of microbial taxa or genes that are shared by all or most humans [236-238]. This definition can be applied to any other animal or plant holobiont. The reported data to date have led to the conclusion that a universal taxonomic organismal core is small [239,240]. However, it can be argued that it may be much larger than currently recognized because of the failure to detect rare microbes, as will be discussed in Section 4, and the rare undetected microbes may have crucial functions when conditions change [241].

In addition to the taxonomic aspect of the core, the definition of "microbiome core" includes also the element of common genes, which implies common functions. A large volume of research during the last twenty years has demonstrated that microbial genes are responsible for many functions essential for the fitness of animal and plant holobionts (reviewed by $[2,238,242,243]$ ). These essential functions must be and are, in fact, transmitted 
between generations [123]. In principle, the microbial genes coding for these functions, not necessarily the taxa, could be transferred vertically or acquired from the environment by a variety of mechanisms, as discussed in this review. As Taxis et al. [244] wrote, "The players may change but the game remains", and Doolittle and Booth [245] wrote "it's the song not the singer." The same functional gene or isogene can be present in different bacteria in the microbiome, i.e., there is gene redundancy in the microbiome [246,247]. Thus, if a particular bacterium possessing an essential functional gene decreases in abundance or is lost, the function may be provided by genes of other bacteria.

Ramos et al. [193] looking for experimental data to support the hypothesis of "It's the song not the singer" tested a number of variables: The first was transmission of functions between generations in databases on zooplankton, mosquito, and plants; the second was the change of functional microbiota with time, up to three years, using a human database; the third was simulation of microbiota communities to test if pairwise interactions lead to stable community compositions. Although the results did not demonstrate transmission of function, they suggested that "the vertically transmitted microbiota starts a predictable change of functions performed by the microbiota over time, whose robustness depends on the arrival of diverse migrants. This succession culminates in a stable functional composition state." They concluded that if their proposed mechanism proves to be well founded for different hosts, it would support the concept of holobionts acting as units of selection in evolution.

Suárez [248] argued that the holobiont/hologenome can act as a genuine level of selection both in the form of an interactor and in the form of a reproducer. To do so, he maintains that the microbiome should be characterized in functional rather than taxonomic terms.

\section{Quantitative Assessment of Transmission of Microbiota}

Reliable and meaningful scientific conclusions from microbiome studies rely on accurate analysis of microbial communities [249]. Several recent publications have discussed procedures for overcoming threats to reproducibility, replicability, robustness, and generalizability in microbiome research [250-254]. In order to evaluate if any particular microbe is transmitted between generations, it is essential to characterize it at the strain level. It is also necessary to detect rare species.

\subsection{False Positives}

With regard to this article, a false positive refers to an incorrect claim that a specific microbe is transmitted from parent to offspring. The vast majority of studies comparing microbiota in parents and offspring has relied on 16S rRNA gene determination, using $>97 \%$ identity to characterize a bacterial species [255]. As many scientists have pointed out $>97 \%$ identity of $16 \mathrm{~S}$ rRNA gene sequences does not prove that two bacteria are identical [256-258]. This is particularly relevant to transmission studies because this methodology cannot determine if the offspring obtained the bacterium vertically from the parent [9]. A different bacterium with $>97 \%$ identity of 16 S rRNA gene sequences could have been acquired from the environment harboring slightly different genes. To overcome this problem, strain-specific gene sequences, although still largely underrepresented in public repositories, can be employed to identify bacteria down to the strain level $[259,260]$. Although not always possible, the most decisive method to prove that a particular bacterium was transmitted from parent to offspring is to perform whole genome sequencing of the bacterium isolated from parent and from offspring [261].

Another source of false positives is bacterial or DNA contamination in reagents used for DNA extraction and PCR [262,263]. Maqsood et al. [264] reported that in his study several infant stool bacterial microbiomes were indistinguishable from buffer background, and thus cannot be attributed to maternal transmission. In a different study, $54 \%$ of bacterial signals in the brain was explained by exogenous DNA contamination, and were thus falsepositives [265]. DNase treatment has been suggested as a method for removing DNA contamination in PCR reagents [263]. 


\subsection{False Negatives}

The failure to find a particular bacterium in the microbiome does not mean it is not there. The more accurate conclusion is that it is not present at the limits of detection used in the experiment. As things stand to date, if a microbial species is present, but rare, it is often not detected [266]. For example, if a particular bacterial species was present in $10^{3}$ copies in the human colon (total bacteria $=10^{13}-10^{14}$ ), it would be necessary to sequence $10^{10}-10^{11} 16 \mathrm{~S}$ rRNA genes to detect it. This is clearly not practical with the existing technology. In fact, statistical analyses indicate that the reported values of bacterial diversity in microbiomes are underestimations [267]. It is important to point out that even a single bacterium has the potential to amplify in numbers when conditions change to the benefit this specific bacterium, and thus may allow the holobiont to evolve by being more adapted to the new condition.

Recent research on the gut microbiota has largely been driven by the advent of modern sequence-based techniques $[268,269]$. Although these are powerful and valuable tools, they have limitations. For example, profiling gut microbiomes by both 16S rRNA gene sequencing and shotgun metagenomic sequencing techniques demonstrated several genera that are missed or underrepresented by each profiling method separately [270].

Another possible source of false negatives are spores. At least $50 \%$ of the bacterial genera from the intestinal microbiota of a healthy individual produce resilient spores, specialized for host-to-host transmission $[271,272]$. However, a phylogenetic assessment of the microbial communities has revealed surprisingly few spore formers [273], probably because spores are known to withstand many traditional methods of DNA isolation and are thus potentially undetectable [274]. The failure to detect rare bacteria and spores makes it difficult to prove or disprove modes of transmission.

\section{Concluding Remarks}

In this article, we discussed the importance of vertical and horizontal transmissions of microbes or functions, in the process of creating a holobiont with its hologenome as a unit of selection in evolution. In general, modes of microbiota transmission are diverse, and probably have evolved to fit the needs and the physical and physiological characteristics of the specific holobiont species.

Summing up the information discussed here, we suggest that the microbiome of holobionts, animals or plants, develops in parallel with the development of the host, eventually creating the mature holobiont. The initial microbiome of the offspring originates usually vertically from the parents, in many cases from the mother, and it has to include the microorganisms that are essential for its development. As the offspring develops, it collects additional microorganisms, which can be foreign, familial, or communal [275]. As was suggested by Fukami [192], Thomas et al. [191], Björk et al. [11], and Ramos et al. [193], eventually the adult microbiome reaches an equilibrium that involves the microbes and functions that are necessary for the survival of the adult holobiont under different conditions. This developmental process is in contrast to the genetic potential of the host that is available from the start.

The microbiome is comprised of a core that is species-specific and includes the essential functions for each developmental stage and environmental condition in addition to diverse microbes that characterize the individual holobiont. The size of the core is still not clear and neither is the question of what forms the core taxa or function, or both. At each point of time, in which the microbiome will be tested for taxa, a certain picture will emerge. This picture will reflect both the core and other individually specific microbes in the particular conditions (diet, health, temperature, etc.,) at the time of sampling. Thus, the picture that emerges, using the techniques available today, does not necessarily reflect the complete potential of microbes of the holobiont. It mirrors the microbes that are abundant (amplified) at the time of sampling, while other microbes that have decreased considerably in number because they are less fit for the present conditions will not be detected. It is important to note that although the latter may not be detected, they remain potential players when 
conditions change. However, while the full microbiome taxa may not be reflected in any specific time, genes from different taxa may fulfill the necessary functions needed for core and other activities.

There are two main advantages for vertical transmission. First, it ensures that the offspring acquires the essential genes that are necessary for the holobiont's fitness and survival, at least at the initial stages, and it acts as a nucleus for construction of the adult microbiome. This is not left to chance. Second, vertically transferred microbes are adapted to life in their hosts (temperature, $\mathrm{pH}$, immune system, etc.), while microbes acquired from the environment may not be as well adapted. In humans, who are the best studied holobiont, strain-level analyses reveal that offspring acquire a large fraction of their microbiota from their parents (mainly, the mother), suggesting vertical transmission of microbiota primarily from the maternal gut, but also from the vagina, skin, mouth, and breast milk $[25,276]$. It has often been reported that gut microbiota in early life is characterized by rapid and large changes in microbial diversity [277-279]. Microbiota that are absent from infants but present in childhood and adults are assumed to be acquired by horizontal transmission, especially from family members $[128,280]$. However, it is possible, even likely, that the bacteria were present in the infant, but below the detection limit and then amplified when conditions changed, especially nutrition. If this hypothesis is correct, there may be more vertical transmission and possible co-evolution than previously considered.

Let us now consider horizontal transmission. As suggested above, in order for a horizontally acquired microorganism to multiply in a host it must be accepted by the host and by the other members of the microbiome and in some cases it may also contribute to the fitness of the holobiont and even be obligatory to its existence. In spite of horizontal transmission being seemingly less accurate than vertical transmission in constructing the holobiont, the squid-Vibrio example may not be a special case, and we may find that horizontal transmissions are more common and obligatory than we can prove at this point of microbiome research. Holobionts many times live within the close environment of their own species-A community [275]. Thus, it seems logical to assume that as long as the holobiont achieves its potential necessary array of microbial functions to fulfill its needs during different life phases and conditions, and create a holobiont with an adult hologenome, it may be of small consequence if the functions are obtained by horizontal or by vertical transmission. To prove the point of the preciseness of core microbiome duplication from one generation, it will be necessary to compare accurately adult microbiomes by deep genome sequencing that will reach the level of even single microbes and by gene or function analysis.

Horizontal transmission has a definite advantage, supplying functions that were not present in the initial vertically transferred stock of microorganisms. It may insert necessary functions for the present and can bring new functions that may be necessary for the near and far future when conditions change, also participating in stable genetic variations and species evolution. The large variations in modes of transmission have an interesting implication: individuals can acquire and transfer symbionts throughout their lives, and not just during their reproductive phase. Furthermore, this flexibility implies that the environment can have an influence on the composition of the hologenome, on the one hand bringing in different microbes with the same functions, and on the other, bringing in new genetic material, assisting in short and long-term adaptation and evolution.

Let us sum up the arguments put forth regarding accurate microbial transmission and their support of the hologenome concept. First, the transmission may be of functions, not necessarily of species; second, horizontal transmission may be as accurate as vertical transmission; third, detection techniques may be limiting; and lastly, microbiomes develop with their host reaching maturity at adulthood. In addition, it should be born in mind that transfer of genetic material of the host from one generation to the next is also not always completely accurate, which is one of the mechanisms conferring uniqueness to offspring and possibilities of variation and evolution, regardless of a large common genetic denominator. 
It is clear that despite the great variation in holobionts and in means of transmission discussed in this review, microbiotas and their functions are, in fact, transferred from one generation of holobionts to the next with fidelity. Such reliable transmission provides a strong basis for each holobiont to be considered a unique biological entity and a level of selection in evolution [2,5], largely maintaining the uniqueness of the entity and conserving the holobiont species from one generation to the next, in addition to contributing to adaptation and evolution of the holobiont [281].

Funding: This research received no external funding.

Conflicts of Interest: The authors declare no conflict of interest.

\section{References}

1. Zilber-Rosenberg, I.; Rosenberg, E. Role of microorganisms in the evolution of animals and plants: The hologenome theory of evolution. FEMS Microbiol. Rev. 2008, 32, 723-735. [CrossRef]

2. Rosenberg, E.; Zilber-Rosenberg, I. The hologenome concept of evolution after 10 years. Microbiome 2018, 6, 78. [CrossRef] [PubMed]

3. Ley, R.E.; Peterson, D.A.; Gordon, J.I. Ecological and evolutionary forces shaping microbial diversity in the human intestine. Cell 2006, 124, 837-848. [CrossRef] [PubMed]

4. Stévenne, C.; Micha, M.; Plumier, J.-C.; Roberty, S. Corals and sponges under the light of the holobiont concept: How microbiomes underpin our understanding of marine ecosystems. Front. Mar. Sci. 2021, 8, 1035. [CrossRef]

5. Roughgarden, J.; Gilbert, S.F.; Rosenberg, E.; Zilber-Rosenberg, I.; Lloyd, E.A. Holobionts as units of selection and a model of their population dynamics and evolution. Biol. Theory 2018, 13, 44-65. [CrossRef]

6. Gilbert, S.F.; Tauber, A.I. Rethinking individuality: The dialectics of the holobiont. Biol. Philos. 2016, 31, 839-853. [CrossRef]

7. Rees, T.; Bosch, T.; Douglas, A.E. How the microbiome challenges our concept of self. PLoS Biol. 2018, 16, e2005358. [CrossRef] [PubMed]

8. Suárez, J. The holobiont/hologenome as a level of selection: An approach to the evolution of multispecies systems. THEORIA Int J. Theory Hist. Found. Sci. 2021, 36, 81-112. [CrossRef]

9. Moran, N.A.; Sloan, D.B. The hologenome concept: Helpful or hollow? PLoS Biol. 2015, 13, e1002311. [CrossRef]

10. Douglas, A.E.; Werren, J.H. Holes in the hologenome: Why host-microbe symbioses are not holobionts. $m$ Bio 2016, 7, e02099-15. [CrossRef]

11. Björk, J.R.; Astudillo-García, C.; Archie, E.; Montoya, J.M. Vertical transmission of sponge microbiota is weak and inconsistent. Nat. Ecol. Evol. 2019, 3, 1172-1183. [CrossRef]

12. Zhou, X.; Wang, J.-T.; Zhang, Z.-F.; Li, W.; Chen, W.; Cai, L. Microbiota in the rhizosphere and seed of rice from China, with reference to their transmission and biogeography. Front. Microbiol. 2020, 11, 995. [CrossRef]

13. Trivedi, P.; Leach, J.E.; Tringe, S.G.; Sa, T.; Singh, B.K. Plant-microbiome interactions: From community assembly to plant health. Nat. Rev. Microbiol. 2020, 18, 607-621. [CrossRef] [PubMed]

14. Guo, J.; Ling, N.; Li, Y.; Li, K.; Ning, H.; Shen, Q.; Guo, S.; Vandenkoornhuyse, P. Seed-borne, endospheric and rhizospheric core microbiota as predictors of plant functional traits across rice cultivars are dominated by deterministic processes. New Phytol. 2021, 230, 2047-2060. [CrossRef]

15. Faddetta, T.; Abbate, L.; Alibrandi, P.; Arancio, W.; Siino, D.; Strati, F.; Arancio, W.; De Filippo, C.; Del Bosco, S.F.; Carimi, F.; et al. The endophytic microbiota of citrus limon is transmitted from seed to shoot highlighting differences of bacterial and fungal community structures. Sci. Rep. 2021, 11, 7078. [CrossRef] [PubMed]

16. David, I.; Canario, L.; Combes, S.; Demars, J. Intergenerational transmission of characters through genetics, epigenetics, microbiota, and learning in livestock. Front. Genet. 2019, 31, 1058. [CrossRef] [PubMed]

17. Yukgehnaish, K.; Kumar, P.; Sivachandran, P.; Marimuthu, K.; Arshad, A.; Paray, B.A.; Arockiaraj, J. Gut microbiota meta-genomics in aquaculture: Factors influencing gut microbiome and its physiological role in fish. Rev. Aquac. 2020, 12, 1903-1927. [CrossRef]

18. Scalvenzi, T.; Clavereau, I.; Bourge, M.; Pollet, N. Gut microbial ecology of Xenopus tadpoles across life stages. bioRxiv 2021. [CrossRef]

19. Chalifour, B.; Li, J. A review of the molluscan microbiome: Ecology, methodology and future. Malacologia 2021, 63, 285-304. [CrossRef]

20. Raulo, A.; Allen, B.E.; Troitsky, T.; Husby, A.; Firth, J.A.; Coulson, T.; Knowles, S.C.L. Social networks strongly predict the gut microbiota of wild mice. ISME J. 2021, 15, 2601-2613. [CrossRef]

21. Browne, H.; Neville, B.; Forster, S.; Lawley, T.D. Transmission of the gut microbiota: Spreading of health. Nat. Rev. Microbiol. 2017, 15, 531-543. [CrossRef] [PubMed]

22. Van Daele, E.; Knol, J.; Belzer, C. Microbial transmission from mother to child: Improving infant intestinal microbiota development by identifying the obstacles. Crit. Rev. Microbiol. 2019, 45, 613-648. [CrossRef]

23. Tochitani, S. Vertical transmission of gut microbiota: Points of action of environmental factors influencing brain development. Neurosci. Res. 2020, 168, 83-94. [CrossRef] [PubMed] 
24. Vandenplas, Y.; Carnielli, V.P.; Ksiazyk, J.; Sanchez Luna, M.; Megacheva, N.; Mosselmans, J.M.; Picaud, J.C.; Possnerh, M.; Singhali, A.; Wabitsch, M. Factors affecting early-life intestinal microbiota development. Nutrition 2020, 78, 110812. [CrossRef]

25. Wang, S.; Ryan, A.; Boyaval, P.; Dempsey, E.M.; Ross, P.; Stanton, C. Maternal vertical transmission affecting early-life microbiota development. Trends Microbiol. 2020, 28, 28-45. [CrossRef] [PubMed]

26. Moeller, A.H.; Suzuki, T.A.; Phifer-Rixey, M.; Nachman, M.W. Transmission modes of the mammalian gut microbiota. Science 2018, 362, 453-457. [CrossRef]

27. Leftwich, P.T.; Edgington, M.P.; Chapman, T. Transmission efficiency drives host-microbe associations. Proc. R. Soc. B 2020, 287, 20200820. [CrossRef] [PubMed]

28. Biesbroek, G.; Sanders, E.A.M.; Roeselers, G.; Wang, X.; Caspers, M.P.M.; Trzciński, K.; Bogaert, D.; Keijser, B.J.F. Deep sequencing analyses of low density microbial communities: Working at the boundary of accurate microbiota detection. PLoS ONE 2012, 7 , e32942. [CrossRef]

29. Hiergeist, A.; Gläsner, J.; Reischl, U.; Gessner, A. Analyses of intestinal microbiota: Culture versus aequencing. ILAR J. 2015, 56, 228-240. [CrossRef]

30. Brandt, J.; Albertsen, M. Investigation of detection limits and the Influence of DNA extraction and primer choice on the observed microbial communities in drinking water samples using $16 \mathrm{~S}$ rRNA gene amplicon sequencing. Front. Microbiol. 2018, 9, 2140. [CrossRef]

31. Ikeda-Ohtsubo, W.; Brugman, S.; Warden, C.H.; Rebel, J.M.J.; Folkerts, G.; Pieterse, C.M.J. Corrigendum: How can we define “Optimal Microbiota?": A comparative review of structure and functions of microbiota of animals, fish, and plants in agriculture. Front. Nutr. 2018, 5, 113. [CrossRef] [PubMed]

32. Sherwin, E.; Bordenstein, S.R.; Quinn, J.L.; Dinan, T.G.; John, F.; Cryan, J.F. Microbiota and the social brain. Science 2019, 366, eaar2016. [CrossRef]

33. Hanaway, P. Diversity: From diet to flora to life. Glob. Adv. Health Med. 2014, 3, 6-8. [CrossRef]

34. Berg, G.; Grube, M.; Schloter, M.; Smalla, K. Unraveling the plant microbiome: Looking back and future perspectives. Front. Microbiol. 2014, 5, 148. [CrossRef]

35. Figueiredo, A.R.T.; Kramer, J. Cooperation and conflict within the microbiota and their effects on animal hosts. Front. Ecol. Evol. 2020, 8, 132. [CrossRef]

36. Savage, D.C. Microbial ecology of the gastrointestinal tract. Ann. Rev. Microbiol. 1977, 31, 107-133. [CrossRef] [PubMed]

37. Ebert, D.; Fields, P.D. Host-parasite co-evolution and its genomic signature. Nat. Rev. Genet. 2020, 21, 754-768. [CrossRef] [PubMed]

38. Funkhouser, L.J.; Bordenstein, S.R. Mom knows best: The universality of maternal microbial transmission. PLoS Biol. 2013, 11, e1001631. [CrossRef]

39. Asker, S.; Jerling, L. Apomixis in Plants; CRC Press: Boca Raton, FL, USA, 1992.

40. Vannier, N.; Mony, C.; Bittebiere, A.K.; Michon-Coudouel, S.; Biget, M.; Vandenkoornhuyse, P. A microorganisms' journey between plant generations. Microbiome 2018, 6, 79. [CrossRef]

41. Kostyuchenko, R.P.; Kozin, V.V. Morphallaxis versus epimorphosis? Cellular and molecular aspects of regeneration and asexual reproduction in annelids. Biol. Bull. Russ. Acad. Sci. 2020, 47, 237-246. [CrossRef]

42. Hörandl, E.; Bast, J.; Brandt, A.; Scheu, S.; Bleidorn, C.; Cordellier, M.; Nowrousian, M.; Begerow, D.; SturmKoen, A.; Verhoeven, K.; et al. Genome evolution of asexual organisms and the paradox of sex in eukaryotes. In Evolutionary Biology: A Transdisciplinary Approach; Pontarotti, P., Ed.; Springer: Cham, Switzerland, 2020. [CrossRef]

43. Yasui, Y.; Tsukamoto, S.; Sugaya, T.; Nishihama, R.; Wang, Q.; Kato, H. Gemma cup-associated MYB1, an ortholog of axillary meristem regulators, is essential in vegetative reproduction in Marchantia polymorpha. Curr. Biol. 2019, 29, 3987-3995. [CrossRef] [PubMed]

44. Riov, J.; Fox, H.; Attias, R.; Shklarb, G.; Farkash-Haimb, L.; Sitbonc, R.; Moshe, Y.; Abu-Abied, M.; Sadot, E.; David-Schwartz, R Improved method for vegetative propagation of mature Pinus halepensis and its hybrids by cuttings. Isr. J. Plant Sci. 2020, 67, 5-15. [CrossRef]

45. Caldwell, J.M.; Donahue, M.; Harvell, D. Host size and proximity to diseased neighbours drive the spread of a coral disease out-break in Hawaii. Proc. R. Soc. B 2018, 285, 20172265. [CrossRef] [PubMed]

46. Ladle, R.J.; Todd, P.A. Sex or sanctuary: How do asexual worms survive the winter? Hydrobiologia 2006, 559, 395-399. [CrossRef]

47. Wessel, G.M.; Fresques, T.; Kiyomoto, M.; Yajima, M.; Zazueta, V. Origin and development of the germ line in sea stars. Genesis 2014, 52, 367-377. [CrossRef] [PubMed]

48. Idan, T.; Goren, L.; Shefer, S.; Brickner, I.; Ilan, M. Does depth matter? Reproduction pattern plasticity in two common sponge species found in both mesophotic and shallow waters. Front. Mar. Sci. 2020, 7, 1078. [CrossRef]

49. Ereskovsky, A.; Geronimo, A.; Pérez, T. Asexual and puzzling sexual reproduction of the Mediterranean sponge Haliclona fulva (Demospongiae): Life cycle and cytological structures. Invertebr. Biol. 2017, 136, 403-421. [CrossRef]

50. Vaughn, D.; Strathmann, R.R. Predators induce cloning in echinoderm larvae. Science 2008, 319, 1503. [CrossRef]

51. Henriques, G.J.B.; van Vliet, S.; Doebeli, M. Multilevel selection favors fragmentation modes that maintain cooperative interactions in multispecies communities. bioRxiv 2021. [CrossRef]

52. Hart, M.W. Life history evolution and comparative developmental biology of echinoderms. Evol. Dev. 2002, 4, 62-71. [CrossRef] 
53. Winston, J.E. Patterns of growth, reproduction and mortality in Bryozoans from the Ross Sea, Antarctica. Bull. Mar. Sci. 1983, 33, 688-702.

54. McCutcheon, J.P. From microbiology to cell biology: When an intracellular bacterium becomes part of its host cell. Curr. Opin. Cell Biol. 2016, 41, 132-136. [CrossRef]

55. Roger, A.J.; Muñoz-Gómez, S.A.; Kamikawa, R. The origin and diversification of mitochondria. Curr. Biol. 2017, 27, R1177-R1192. [CrossRef]

56. DeLuca, S.Z.; O'Farrell, P.H. Barriers to male transmission of mitochondrial DNA in sperm development. Dev. Cell 2012, 22, 660-668. [CrossRef]

57. Fukasawa, Y.; Oda, T.; Tomii, K.; Imai, K. Origin and evolutionary alteration of the mitochondrial import system in eukaryotic lineages. Mol. Biol. Evol. 2017, 34, 1574-1586. [CrossRef]

58. Kormutak, A.; Galgoci, M.; Sukenikova, D.; Bolecek, P.; Libantova, J.; Gőmőry, D. Maternal inheritance of chloroplast DNA in Pinus mugo Turra: A case study of Pinus mugo $\times$ Pinus sylvestris crossing. Plant Syst. Evol. 2018, 304, 71-76. [CrossRef]

59. Sun, S.; Zhou, X.; Li, Z.; Song, H.-Y.; Long, Z.-C.; Fu, P.-C. Intra-individual heteroplasmy in the Gentiana tongolensis plastid genome (Gentianaceae). PeerJ 2019, 7, e8025. [CrossRef]

60. Baumann, P.; Lai, C.Y.; Roubakhsh, D.; Rouhbakhsh, D.; Moran, N.A.; Clark, M.A. Genetics, physiology, and evolutionary rela-tionships of the genus Buchnera-Intracellular symbionts of aphids. Annu. Rev. Microbiol. 1995, 49, 55-94. [CrossRef]

61. Baumann, P. Biology of bacteriocyte-associated endo-symbionts of plant sap-sucking insects. Annu. Rev. Microbiol. 2005, 59, 155-189. [CrossRef] [PubMed]

62. Wilkinson, T.L.; Fukatsu, T.; Shikawa, H. Transmission of symbiotic bacteria Buchnera to parthenogenetic embryos in the aphid Acyrthosiphon pisum (Hemiptera: Aphidoidea). Arth. Struct. Dev. 2003, 32, 241-245. [CrossRef]

63. Foray, V.; Pérez-Jiménez, M.M.; Fattouh, N.; Landmann, F. Wolbachia control stem cell behavior and stimulate germline proliferation in filarial nematodes. Dev. Cell 2018, 45, 198-211. [CrossRef]

64. Werren, J.; Baldo, L.; Clark, M. Wolbachia: Master manipulators of invertebrate biology. Nat. Rev. Microbiol. 2008, 6, 741-751. [CrossRef]

65. Fisher, R.; Henry, L.; Cornwallis, C.; Kiers, E.T.; West, S.A. The evolution of host-symbiont dependence. Nat. Commun. 2017, 8, 15973. [CrossRef]

66. Moran, N.A.; McCutcheon, J.P.; Nakabachi, A. Genomics and evolution of heritable bacterial symbionts. Annu. Rev. Genet. 2008, 42, 165-190. [CrossRef]

67. McCutcheon, J.P.; Boyd, B.M.; Dale, C. The life of an insect endosymbiont from the cradle to the grave. Curr. Biol. 2019, 29, R485-R495. [CrossRef] [PubMed]

68. Moran, N.A.; Bennett, G.M. The tiniest tiny genomes. Annu. Rev. Microbiol. 2014, 68, 195-215. [CrossRef] [PubMed]

69. Quigley, K.M.; Warner, P.A.; Bay, L.K.; Willis, B.L. Unexpected mixed-mode transmission and moderate genetic regulation of Symbiodinium communities in a brooding coral. Heredity 2018, 121, 524-536. [CrossRef]

70. Schmitt, S.; Tsai, P.; Bell, J.; Fromont, J.; Ilan, M.; Lindquist, N.; Perez, T.; Rodrigo, A.; Schupp, P.J.; Vacelet, J.; et al. Assessing the complex sponge microbiota: Core, variable and species-specific bacterial communities in marine sponges. ISME J. 2012, 6, 564-576. [CrossRef] [PubMed]

71. Hassan, B.; Siddiqui, J.A.; Xu, Y. Vertically transmitted gut bacteria and nutrition influence the immunity and fitness of Bactrocera dorsalis larvae. Front. Microbiol. 2020, 11, 596352. [CrossRef]

72. Hosokawa, T.; Hironaka, M.; Inadomi, K.; Mukai, H.; Nikoh, N.; Fukatsu, T. Diverse strategies for vertical symbiont transmission among subsocial stinkbugs. PLoS ONE 2013, 8, e65081. [CrossRef]

73. Perlmutter, J.I.; Bordenstein, S.R. Microorganisms in the reproductive tissues of arthropods. Nat. Rev. Microbiol. 2020, 18, 97-111. [CrossRef]

74. Shang, Y.; Kumar, S.; Oakley, B.; Kim, W.K. Chicken gut microbiota: Importance and detection technology. Front. Vet. Sci. 2018, 5 , 254. [CrossRef]

75. Ding, J.; Dai, R.; Yang, L.; He, C.; Xu, K.; Liu, S.; Zhao, W.; Xiao, L.; Luo, L.; Zhang, Y.; et al. Inheritance and establishment of gut microbiota in chickens. Front. Microbiol. 2017, 10, 1967. [CrossRef]

76. Lee, S.; La, T.M.; Lee, H.J.; Choi, I.-S.; Song, C.-S.; Park, S.-Y.; Lee, J.B.; Lee, S.W. Characterization of microbial communities in the chicken oviduct and the origin of chicken embryo gut microbiota. Sci. Rep. 2019, 9, 6838. [CrossRef]

77. Trevelline, B.K.; MacLeod, K.J.; Knutie, S.A.; Langkilde, T.; Koh, K.D. In ovo microbial communities: A potential mechanism for the initial acquisition of gut microbiota among oviparous birds and lizards. Biol. Lett. 2018, 14, 20180225. [CrossRef] [PubMed]

78. Aagaard, K.; Ma, J.; Antony, K.M.; Ganu, R.; Petrosino, J.; Versalovic, J. The placenta harbors a unique microbiome. Sci. Transl. Med. 2014, 6, 237ra65. [CrossRef] [PubMed]

79. Collado, M.C.; Rautava, S.; Aakko, J.; Isolauri, E. Human gut colonization may be initiated in utero by distinct microbial com-munities in the placenta and amniotic fluid. Sci. Rep. 2016, 6, 23129. [CrossRef]

80. Gomez-Arango, L.F.; Barrett, H.L.; McIntyre, H.D.; Callaway, L.K.; Morrison, M.; Nitert, M.N. Contributions of the maternal oral and gut microbiome to placental microbial colonization in overweight and obese pregnant women. Sci. Rep. 2017, 7, 2860. [CrossRef] 
81. Seferovic, M.D.; Pace, R.M.; Carroll, M.; Belfort, B.; Major, A.M.; Chu, D.M.; Racusin, D.A.; Castro, E.C.C.; Muldrew, K.L.; Versalovic, J.; et al. Visualization of microbes by $16 \mathrm{~S}$ in situ hybridization in term and preterm placentas without intra-amniotic infection. Am. J. Obstet. Gynecol. 2019, 221, 146.e1-146.e23. [CrossRef] [PubMed]

82. Borghi, E.; Massa, V.; Severgnini, M.; Fazio, G.; Avagliano, L.; Menegola, E.; Bulfamante, G.P.; Morace, G.; Borgo, F. Antenatal microbial colonization of mammalian gut. Reprod. Sci. 2019, 26, 1045-1053. [CrossRef] [PubMed]

83. Coscia, A.; Bardanzellu, F.; Caboni, E.; Fanos, V.; Giampietro Peroni, D. When a neonate is born, so is a microbiota. Life 2021, 11, 148. [CrossRef]

84. Guzman, C.E.; Wood, J.L.; Egidi, E.; White-Monsant, A.C.; Semenec, L.; Grommen, S.V.H.; Hill-Yardin, E.L.; De Groef, B.; Franks, A.E. A pioneer calf foetus microbiome. Sci. Rep. 2020, 10, 17712. [CrossRef] [PubMed]

85. de Goffau, M.C.; Lager, S.; Sovio, U.; Gaccioli, F.; Cook, E.; Peacock, S.J.; Parkhill, J.; Charnock-Jones, D.S.; Smith, G.C.S. Human placenta has no microbiome but can contain potential pathogens. Nature 2019, 572, 329-334.

86. Gschwind, R.; Fournier, T.; Kennedy, S.; Tsatsaris, V.; Cordier, A.; Barbut, F.; Butel, M.; Wydau-Dematteis, S. Evidence for contamination as the origin for bacteria found in human placenta rather than a microbiota. PLoS ONE 2020, 15, e0237232. [CrossRef]

87. Kuperman, A.A.; Zimmerman, A.; Hamadia, S.; Ziv, O.; Gurevich, V.; Fichtman, B.; Gavert, N.; Straussman, R.; Rechnitzer, H.; Barzilay, M.; et al. Deep microbial analysis of multiple placentas shows no evidence for a placental microbiome. BJOG 2020, 127, 159-169. [CrossRef] [PubMed]

88. Sterpu, I.; Fransson, E.; Hugerth, L.W.; Du, J.; Pereira, M.; Cheng, L.; Radu, S.A.; Calderón-Pérez, L.; Zha, Y.; Angelidou, P.; et al. No evidence for a placental microbiome in human pregnancies at term. Am. J. Obstet. Gynecol. 2021, 224, 296.e1-296.e23. [CrossRef]

89. Blaser, M.J.; Devkota, S.; McCoy, K.D.; Relman, D.A.; Yassour, M.; Young, V.B. Lessons learned from the prenatal microbiome controversy. Microbiome 2021, 9, 8. [CrossRef] [PubMed]

90. Cope-Selby, N.; Cookson, A.; Squance, M.; Donnison, I.; Flavell, R.; Farrar, K. Endophytic bacteria in Miscanthus seed: Implications for germination, vertical inheritance of endophytes, plant evolution and breeding. GCB Bioenergy 2017, 9, 57-77. [CrossRef]

91. Shahzad, R.; Khan, A.L.; Saqib Bilal, S.; Asaf, S.; Lee, I.-J. What is there in seeds? Vertically transmitted endophytic resources for sustainable improvement in plant growth. Front. Plant Sci. 2018, 9, 24. [CrossRef]

92. Taulé, C.; Vaz-Jauri, P.; Battistoni, F. Insights into the early stages of plant-endophytic bacteria interaction. World J. Microbiol. Biotechnol. 2021, 37, 13. [CrossRef]

93. Geisen, S.; Kostenko, O.; Cnossen, M.C.; ven Hooven, F.C.; Vreš, B.; van der Putten, W.H. Seed and root endophytic fungi in a range expanding and a related plant species. Front. Microbiol. 2017, 8, 1645. [CrossRef]

94. Bo, T.-B.; Zhang, X.-Y.; Kol, K.D.; Wen, J.; Tian, S.-J.; Wang, D.-H. Coprophagy prevention alters microbiome, metabolism, neuro-chemistry, and cognitive behavior in a small mammal. ISME J. 2020, 14, 2625-2645. [CrossRef]

95. Soave, O.; Brand, C.D. Coprophagy in animals a review. Cornell Vet. 1991, 81, 357-364. [PubMed]

96. Kovacs, M.; Szendro, Z.; Milisits, G.; Bóta, B.; Bíró-Németh, E.; Radnai, I.; Pósa, R.; Bónai, A.; Kovács, F.; Horn, P. Effect of nursing methods and feces consumption on the development of bacteroides, lactobacillus and coliform flora in the caecum of the new-born rabbits. Reprod. Nutr. Dev. 2006, 46, 205-210. [CrossRef]

97. Combes, S.; Gidenne, T.; Cauquil, L.; Bouchez, O.; Fortun-Lamothe, L. Coprophagous behavior of rabbit pups affects implantation of cecal microbiota and health status. J. Anim. Sci. 2014, 92, 652-665. [CrossRef] [PubMed]

98. Brown, A.S. The health of Australia's koalas: More research is needed urgently. Med. J. Aust. 1988, 149, 662-664. [CrossRef]

99. Osawa, R.; Blanshard, W.H.; Ocallaghan, P.G. Microbiological studies of the intestinal microflora of the koala, Phascolarctos cinereus. II. Pap, a special maternal feces consumed by juvenile koalas. Aust. J. Zool. 1993, 41, 611-620. [CrossRef]

100. Brune, A.; Dietrich, C. The gut microbiota of termites: Digesting the diversity in the light of ecology and evolution. Annu. Rev. Microbiol. 2015, 69, 145-166. [CrossRef]

101. Nalepa, C.A. Origin of mutualism between termites and flagellated gut protists: Transition from horizontal to vertical transmission Front. Ecol. Evol. 2020, 8, 14. [CrossRef]

102. Brune, A. Microbial symbioses in the digestive tract of lower termites. In Beneficial Microorganisms in Multicellular Life Forms; Rosenberg, E., Gophna, U., Eds.; Springer: Heidelberg, Germany, 2011; pp. 3-25.

103. LeBoeuf, A.C. Trophallaxis. Curr Biol. 2017, 27, R1299-R1300. [CrossRef]

104. Zimmer, M.; Topp, W. The role of coprophagy in nutrient release from feces of phytophagous insects. Soil Biol. Biochem. 2002, 34, 1093-1099. [CrossRef]

105. Salem, H.; Florez, L.; Gerardo, N.; Kaltenpoth, M. An out-of-body experience: The extracellular dimension for the transmission of mutualistic bacteria in insects. Proc. Biol. Sci. 2015, 282, 20142957. [CrossRef]

106. van Dongen, W.F.D.; White, J.; Brand, H.B.; Ksiazyk, J.; Lagström, H.; Luna, M.S.; Migacheva, N.; Mosselmans, J.-M.; Picaud, J.-C.; Possner, M.; et al. Age-related differences in the cloacal microbiota of wild bird species. BMC Ecol. 2013, 13, 11. [CrossRef] [PubMed]

107. Wallace, E.K.; Herrelko, E.S.; Koskie, S.E.; Vick, S.-J.; Buchanan-Smith, H.M.; Slocombe, K.E. Exploration of potential triggers for self-directed behaviours and regurgitation and reingestion in zoo-housed chimpanzees. Appl. Anim. Behav. Sci. 2019, 221, 104878. [CrossRef] 
108. Laméris, D.W.; Staes, N.; Salas, M.; Matthyssen, S.; Verspeek, J.; Stevens, M.G. The influence of sex, rearing history, and personality on abnormal behaviour in zoo-housed bonobos (Pan paniscus). Appl. Anim. Behav. Sci. 2021, 234, 105178. [CrossRef]

109. Wang, Y.; Rozen, D.E. Gut microbiota colonization and transmission in the burying beetle Nicrophorus vespilloides throughout development. J. Clin. Microbiol. 2017, 83, e03250-16. [CrossRef]

110. Luo, Y.; Wang, X.; Ma, Y.; Li, X.K. The biological function of pigeon crop milk and the regulation of its production. Hereditas 2017, 39, 1158-1167.

111. Gillespie, M.J.; Stanley, D.; Chen, H.; Donald, J.A.; Nicholas, K.R.; Moore, R.J.; Crowley, T.M. Functional similarities between pigeon 'milk' and mammalian milk: Induction of immune gene expression and modification of the microbiota. PLoS ONE 2012, 7, e48363. [CrossRef]

112. Dietz, M.W.; Salles, J.F.; Hsu, B.; Dijkstra, C.; Groothuis, T.; van der Velde, M.; Verkuil, Y.; Tielema, B.I. Prenatal transfer of gut bacteria in rock pigeon. Microorganisms 2019, 8, 61. [CrossRef] [PubMed]

113. Ding, J.; Liao, N.; Zheng, Y.; Yang, L.; Zhou, H.; Xu, K.; Han, C.; Luo, H.; Qin, C.; Tang, C.; et al. The composition and function of pigeon milk microbiota transmitted from parent pigeons to squabs. Front. Microbiol. 2020, 11, 1789. [CrossRef]

114. Sakwinska, O.; Foata, F.; Berger, B.; Brüssow, H.; Combremont, S.; Mercenier, A.; Dogra, S.; Soh, E.; Yen, J.C.K.; Heong, G.Y.S.; et al. Does the maternal vaginal microbiota play a role in seeding the microbiota of neonatal gut and nose? Benef. Microbes 2017, 8 , 763-778. [CrossRef] [PubMed]

115. Reyman, M.; van Houten, M.A.; van Baarle, D.; Bosch, A.A.T.M.; Man, W.H.; Chu, M.L.N.; Arp, K.; Watson, R.L.; Sanders, E.A.M.; Fuentes, S.; et al. Impact of delivery mode-associated gut microbiota dynamics on health in the first year of life. Nat. Commun. 2019, 10, 4997. [CrossRef] [PubMed]

116. Hauffe, H.C.; Barelli, C. Conserve the germs: The gut microbiota and adaptive potential. Conserv. Genet. 2019, 20, 19-27. [CrossRef]

117. Perez-Lamarque, B.; Morlon, H. Characterizing symbiont inheritance during host-microbiota evolution: Application to the great ape's gut microbiota. Mol. Ecol. Resour. 2019, 19, 1659-1671. [CrossRef]

118. Ingala, M.R.; Simmons, N.B.; Perkinsa, S.L. Bats are an untapped system for understanding microbiome evolution in mammals. mSphere 2018, 3, e00397-18. [CrossRef]

119. Parker, E.S.; Dury, G.J.; Moczek, A.P. Transgenerational developmental effects of species-specific maternally transmitted microbiota in Onthophagus dung beetles. Ecol. Entomol. 2019, 44, 274-282. [CrossRef]

120. Li, X.; Yu, Y.; Feng, W.; Gong, Y. Host species as a strong determinant of the intestinal microbiota of fish larvae. J. Microbial. 2012, 50, 29-37. [CrossRef] [PubMed]

121. Baldo, L.; Riera, J.L.; Tooming-Klunderud, A.; Albà, M.M.; Salzburger, W. Gut microbiota dynamics during dietary shift in Eastern African cichlid fishes. PLoS ONE 2015, 10, e0127462. [CrossRef]

122. Mändar, R.; Mikelsaar, M. Transmission of mother's microflora to the newborn at birth. Biol. Neonate. 1996, 69, 30-35. [CrossRef]

123. Vaishampayan, P.A.; Kuehl, J.V.; Froula, J.L.; Morgan, J.L.; Ochman, H.; Francino, M.P. Comparative metagenomics and population dynamics of the gut microbiota in mother and infant. Genome Biol. Evol. 2010, 2010, 53-66. [CrossRef]

124. Li, W.; Tapiainen, T.; Brinkac, L.; Lorenzi, H.A.; Moncera, K.; Tejesvi, M.V.; Salo, J.; Nelson, K.E. Vertical transmission of gut microbiome and antimicrobial resistance genes in infants exposed to antibiotics at birth. J. Infect. Dis. 2021, 224, 1236-1246. [CrossRef]

125. Long, G.; Hu, y.; Tao, E.; Chen, B.; Shu, X.; Zhen, W.; Jiang, M. The Influence of Cesarean Section on the Composition and Development of Gut Microbiota During the First 3 Months of Life. Front. Microbiol. 2021, 12, 691312. [CrossRef]

126. Dominguez-Bello, M.G.; De Jesus-Laboy, K.M.; Shen, N.; Cox, L.M.; Amir, A.; Gonzalez, A.; Bokulich, N.A.; Song, S.J.; Hoashi, M.; Juana, I.; et al. Partial restoration of the microbiota of cesarean-born infants via vaginal microbial transfer. Nat. Med. 2016, 22, 250-253. [CrossRef] [PubMed]

127. Hoang, D.M.; Levy, E.I.; Vandenplas, Y. The impact of Caesarean section on the infant gut microbiome. Acta Paediatr. 2021, 110, 60-67. [CrossRef] [PubMed]

128. Brito, I.L.; Gurry, T.; Zhao, S.; Huang, S.K.; Shea, P.; Naisilisili, W.; Jenkins, A.P.; Jupiter, S.D.; Gevers, D.; Alm, E.J. Transmission of human-associated microbiota along family and social networks. Nat. Microbiol. 2019, 4, 964-971. [CrossRef]

129. Zhang, N.; Chen, W.; Chan, P.-T.; Yen, H.-L.; Tang, J.W.-T.; Li, Y. Close contact behavior in indoor environment and transmission of respiratory infection. Int. J. Indoor Environ. Health 2020, 30, 645-661. [CrossRef] [PubMed]

130. Kort, R.; Caspers, M.; van de Graaf, A.; van Egmond, W.; Keijser, B.; Roeselers, G. Shaping the oral microbiota through intimate kissing. Microbiome 2014, 2, 41. [CrossRef] [PubMed]

131. Sarkar, A.; Harty, S.; Johnson, K.V.-A.; Moeller, A.H.; Carmody, R.N.; Lehto, S.M.; Erdman, S.E.; Dunbar, R.I.M.; Burnet, P.W.J. The role of the microbiome in the neurobiology of social behavior. Biol. Rev. Camb. Philos. Soc. 2020, 95, 1131-1166. [CrossRef]

132. Kuthyar, S.; Manus, M.B.; Amato, K.R. Leveraging non-human primates for exploring the social transmission of microbes. Curr. Opin. Microbiol. 2019, 50, 8-14. [CrossRef]

133. Lombardo, M.P. Access to mutualistic endosymbiotic microbes: An underappreciated benefit of group living. Behav. Ecol. Sociobiol. 2008, 62, 479-497. [CrossRef]

134. Kulkarni, S.; Heeb, P. Social and sexual behaviours aid transmission of bacteria in birds. Behav. Process. 2007, 74, 88-92. [CrossRef] [PubMed] 
135. Linz, B.; Balloux, F.; Moodley, Y.; Manica, A.; Liu, H.; Roumagnac, P.; Falush, D.; Stamer, C.; Prugnolle, F.; van der Merwe, S.W.; et al. An African origin for the intimate association between humans and Helicobacter pylori. Nature 2007, 445, 915-918. [CrossRef] [PubMed]

136. Pereira-Marques, J.; Ferreira, R.M.; Pinto-Ribeiro, I.; Figueiredo, C. Helicobacter pylori infection, the gastric microbiome and gastric cancer. Adv. Exp. Med. Biol. 2019, 1149, 195-210. [CrossRef] [PubMed]

137. Kakelar, M.; Barzegari, H.; Dehghani, J.; Hanifian, S.; Saeedi, N.; Barar, J.; Omidi, Y. Pathogenicity of Helicobacter pylori in cancer development and impacts of vaccination. Gastric Cancer 2019, 22, 23-36. [CrossRef]

138. Reshetnyak, V.I.; Burmistrov, A.I.; Maev, I.V. Helicobacter pylori: Commensal, symbiont or pathogen? World J. Gastroenterol. 2021, 27, 545-560. [CrossRef]

139. Dominguez-Bello, M.G.; Blaser, M.J. The human microbiota as a marker for migrations of individuals and populations. Annu. Rev. Anthropol. 2011, 40, 451-474. [CrossRef]

140. Waskito, L.A.; Yamaoka, Y. The story of Helicobacter pylori: Depicting human migrations from the phylogeography. In Helicobacter pylori in Human Diseases: Advances in Experimental Medicine and Biology; Kamiya, S., Backert, S., Eds.; Springer: Cham, Switzerland, 2019; p. 1149.

141. Sandoval-Motta, S.; Aldana, M.; Martínez-Romero, E.; Frank, A. The human microbiome and the missing heritability problem. Front. Genet. 2017, 8, 80. [CrossRef]

142. Grieneisen, L.; Dasari, M.; Gould, T.J.; Björk, L.R.; Grenier, J.-C.; Yotova, V.; Jansen, D.; Gottel, N.; Gordon, J.B.; Blekhman, R.; et al. Gut microbiome heritability is nearly universal but environmentally contingent. Science 2021, 373, 181-186. [CrossRef]

143. Drell, T.; Štšepetova, J.; Simm, J.; Rull, K.; Aleksejeva, A.; Antson, A.; Tillmann, V.; Metsis, M.; Sepp, E.; Salumets, A.; et al. The influence of different maternal microbial communities on the development of infant gut and oral microbiota. Sci. Rep. 2017, 7, 9940. [CrossRef]

144. Yang, J.; Yao, S.; Cheng, K.; Xu, L.; Hou, L.; Wei, Y.; Feng, H.; Yu, X.; Zhang, X.; Tong, X.; et al. Comparison of meconium microbiome in dizygotic and monozygotic twins born by Caesarean section (CS). Front. Microbiol. 2020, 11, 1139. [CrossRef]

145. Milani, C.; Mancabelli, L.; Lugli, G.A.; Duranti, S.; Turroni, F.; Ferrario, C.; Mangifesta, M.; Viappiani, A.; Ferretti, P.; Gorfer, V.; et al. Exploring vertical transmission of bifidobacteria from mother to child. Appl. Environ. Microbiol. 2015, 81, 7078-7087. [CrossRef] [PubMed]

146. Duranti, S.; Lugli, G.A.; Mancabelli, L.; Armanini, F.; Turroni, F.; James, K.; Ferretti, P.; Gorfer, V.; Ferrario, C.; Milani, C.; et al. Maternal inheritance of bifidobacterial communities and bifidophages in infants through vertical transmission. Microbiome 2017, 5, 66. [CrossRef]

147. Murphy, K.; Curley, D.; O'Callaghan, T.; O'Shea, C.-A.; Dempsey, E.M.; O’Toole, P.W.; Ross, R.P.; Ryan, A.; Stantona, C. The composition of human milk and infant faecal microbiota over the first three months of life: A pilot study. Sci. Rep. 2017, 7, 40597. [CrossRef] [PubMed]

148. Korpela, K.; Costea, P.; Coelho, L.P.; Kandels-Lewis, S.; Willemsen, G.; Boomsma, D.I.; Segata, N.; Bork, P. Selective maternal seeding and environment shape the human gut microbiome. Genome Res. 2018, 28, 561-568. [CrossRef] [PubMed]

149. Sakwinska, O.; Moine, D.; Delley, M.; Combremont, S.; Rezzonico, E.; Descombes, P.; Vinyes-Pares, G.; Zhang, Y.; Wang, P.; Thakkar, S.K. Microbiota in breast milk of Chinese lactating mothers. PLoS ONE 2016, 11, e0160856. [CrossRef]

150. van den Elsen, L.W.J.; Garssen, J.; Burcelin, R.; Verhasselt, V. Shaping the gut microbiota by breastfeeding. The gateway to allergy prevention? Front. Pediatr. 2019, 7, 47. [CrossRef]

151. Malinowska-Pańczyk, E.; Królik, K.; Skorupska, K.; Puta, K.; Martysiak-Żurowska, D.; Kiełbratowska, B. Microwave heat treatment application to pasteurization of human milk. Innov. Food Sci. Emerg. Technol. 2019, 52, 42-48. [CrossRef]

152. Oikonomou, G.; Addis, M.F.; Chassard, C.; Nader-Macias, M.E.F.; Grant, I.; Delbès, C.; Le Loir, Y.; Even, S. Milk microbiota: What are we exactly talking about? Front. Microbiol. 2020, 11, 60. [CrossRef]

153. Williams, J.E.; Carrothers, J.M.; Lackey, K.A.; Beatty, N.F.; Brooker, S.L.; Peterson, H.K.; Steinkamp, K.M.; York, M.A.; Shafii, B.; Price, W.J.; et al. Strong multivariate relations exist among milk, oral, and fecal microbiomes in mother-infant dyads during the first six months postpartum. J. Nutr. 2019, 149, 902-914. [CrossRef]

154. Asnicar, F.; Manara, S.; Zolfo, M.; Truong, D.T.; Scholz, M.; Mach, F.E.; Armanini, F.; Ferretti, P.; Gorfer, V.; Pedrotti, A.; et al. Studying vertical microbiome transmission from mothers to infants by strain-level metagenomic profiling. $m S y s t e m s \mathbf{2 0 1 7}, 2$, e00164-16. [CrossRef]

155. Turroni, F.; Milani, C.; Duranti, S.; Ferrario, C.; Lugli, G.A.; Mancabelli, L.; van Sinderen, D.; Ventura, M. Bifidobacteria and the infant gut: An example of co-evolution and natural selection. Cell Mol. Life Sci. 2018, 75, 103-118. [CrossRef]

156. Bäckhed, F.; Roswall, J.; Peng, Y.; Feng, Q.; Jia, H.; Kovatcheva, P.; Li, D.Y.; Xia, Y.; Xie, H.; Zhong, H.; et al. Dynamics and stabilization of the human gut microbiome during the first year of life. Cell Host Microbe 2015, 17, 690-703. [CrossRef] [PubMed]

157. Milani, C.; Duranti, S.; Bottacini, F.; Casey, E.; Turroni, F.; Mahony, J.; Belzer, C.; Palacio, S.D.; Montes, S.A.; Mancabelli, L.; et al. The first microbial colonizers of the human gut: Composition, activities, and health implications of the infant gut microbiota. Microbiol. Mol. Biol. Rev. 2017, 81, e00036-17. [CrossRef] [PubMed]

158. Vandenplas, Y.; Berger, B.; Carnielli, V.P.; Ksiazyk, J.; Lagström, H.; Luna, M.S.; Migacheva, N.; Mosselmans, J.-M.; Picaud, J.-C.; Possner, M.; et al. Human milk oligosaccharides: 2'-fucosyllactose (2'-FL) and lacto-N-neotetraose (LNnT) in infant formula. Nutrients 2018, 10, 1161. [CrossRef] [PubMed] 
159. James, K.; Bottacini, F.; Contreras, J.I.S.; Vigoureux, M.; Egan, M.; Motherway, M.O.; Holmes, E.; van Sinderen, D. Metabolism of the predominant human milk oligosaccharide fucosyllactose by an infant gut commensal. Sci. Rep. 2019, 9, 15427. [CrossRef] [PubMed]

160. Delavenne, E.; Mounier, J.; Asmani, K.; Jany, J.-L.; Barbier, G.; Le Blay, G. Fungal diversity in cow, goat and ewe milk. Int. J. Food Microbiol. 2011, 151, 247-251. [CrossRef]

161. Boix-Amorós, A.; Martinez-Costa, C.; Quero, A.; Collado, M.C.; Mira, A. Multiple approaches detect the presence of fungi in human breastmilk samples from healthy mothers. Sci. Rep. 2019, 7, 13016. [CrossRef] [PubMed]

162. Prendergast, A.J.; Goga, A.E.; Waitt, C.; Gessain, A.; Taylor, G.P.; Rollins, N.; Abrams, E.J.; Lyall, E.H.; Van de Perre, P. Transmission of CMV, HTLV-1, and HIV through breastmilk. Lancet Child Adolesc. Health 2019, 3, 264-273. [CrossRef]

163. Stinson, L.F.; Sindi, A.S.M.; Cheema, A.S.; Lai, C.T.; Mühlhäusler, B.S.; Wlodek, M.E.; Payne, M.S.; Geddes, D.T. The human milk microbiome: Who, what, when, where, why, and how? Nutr. Rev. 2021, 79, 529-543. [CrossRef]

164. Meng, S.; Chen, B.; Yang, J.; Wang, J.; Zhu, D.; Meng, Q.; Zhang, L. Study of microbiomes in aseptically collected samples of human breast tissue using needle biopsy and the potential role of in situ tissue microbiomes for promoting malignancy. Front. Oncol. 2018, 8, 318. [CrossRef]

165. Urbaniak, C.; Gloor, G.B.; Brackstone, M.; Scott, L.; Tangney, M.; Reid, G. The microbiota of breast tissue and its association with breast cancer. Appl. Environ. Microbiol. 2016, 82, 5039-5048. [CrossRef] [PubMed]

166. Shively, C.A.; Register, T.C.; Appt, S.E.; Clarkson, T.B.; Uberseder, B.; Clear, K.Y.J.; Wilson, A.S.; Chiba, A.; Tooze, J.A.; Cook, K.L. Consumption of Mediterranean versus western diet leads to distinct mammary gland microbiome populations. Cell Rep. 2018, 25, 47-56. [CrossRef]

167. Urbaniak, C.; Cummins, J.; Brackstone, M.; Macklaim, J.M.; Gloor, G.B.; Baban, C.K.; Scott, L.; O’Hanlon, D.M.; Burton, J.P.; Francis, K.P.; et al. Microbiota of human breast tissue. Appl. Environ. Microbiol. 2014, 80, 3007-3014. [CrossRef]

168. Fernández, L.; Pannaraj, P.S.; Rautava, S.; Rodríguez, J.M. The microbiome of the human mammary ecosystem. Front. Cell Infect. Microbiol. 2020, 10, 586667. [CrossRef] [PubMed]

169. De Andrés, J.; Manzano, S.; Garcia, C.; Rodriguez, J.M.; Espinosa-Martos, I.; Jiménez, E. Modulatory effect of three probiotic strains on infants' gut microbial composition and immunological parameters on a placebo-controlled, double-blind, randomized study. Benef. Microbes 2018, 9, 573-584. [CrossRef] [PubMed]

170. Fernández, L.; Langa, S.; Martín, V.; Maldonado, A.; Jiménez, E.; Martín, R.; Rodríguez, J.M. The human milk microbiota: Origin and potential roles in health and disease. Pharmacol. Res. 2013, 69, 1-10. [CrossRef]

171. Moossavi, S.; Azad, M.B. Origins of human milk microbiota: New evidence and arising questions. Gut Microbes 2020, $12,1667722$. [CrossRef]

172. Rodríguez, J.M. The origin of human milk bacteria: Is there a bacterial entero-mammary pathway during late pregnancy and lactation? Adv. Nutr. 2014, 5, 779-784. [CrossRef]

173. Ochman, H.; Worobey, M.; Kuo, C.H.; Ndjango, J.-B.N.; Peeters, M.; Hahn, B.H.; Hugenholtz, P. Evolutionary relationships of wild hominids recapitulated by gut microbial communities. PLoS Biol. 2010, 8, e1000546. [CrossRef]

174. Yildirim, S.; Yeoman, C.J.; Sipos, M.; Torralba, M.; Wilson, B.A.; Goldberg, T.L.; Stumpf, R.M.; Leigh, S.R.; White, B.A.; Nelson, K.E.; et al. Characterization of the fecal microbiome from non-human wild primates reveals species-specific microbial communi-ties. PLoS ONE 2010, 5, e13963. [CrossRef]

175. Sanders, J.G.; Powell, S.; Kronauer, D.J.; Vasconcelos, H.L.; Frederickson, M.E.; Pierce, N.E. Stability and phylogenetic correlation in gut microbiota: Lessons from ants and apes. Mol. Ecol. 2014, 23, 1268-1283. [CrossRef] [PubMed]

176. Moeller, A.H.; Caro-Quintero, A.; Mjungu, D.; Georgiev, A.V.; Lonsdorf, E.V.; Muller, M.N.; Pusey, A.E.; Peeters, M.; Hahn, B.H.; Ochman, H. Co-speciation of gut microbiota with hominids. Science 2016, 353, 380-382. [CrossRef]

177. Nishida, A.H.; Ochman, H. A great-ape view of the gut microbiome. Nat. Rev. Genet. 2019, 20, 195-206. [CrossRef] [PubMed]

178. Rampelli, S.; Turroni, S.; Mallol, C.; Hernandez, C.; Galván, B.; Sistiaga, A.; Biagi, E.; Astolfi, A.; Brigidi, P.; Benazzi, S.; et al Components of a Neanderthal gut microbiome recovered from fecal sediments from El Salt. Commun. Biol. 2012, 4, 169. [CrossRef] [PubMed]

179. Meehan, C.J.; Beiko, R.G.A. Phylogenomic view of ecological specialization in the Lachnospiraceae, a family of digestive tract-associated bacteria. Genome Biol. Evol. 2014, 6, 703-713. [CrossRef] [PubMed]

180. Kopac, S.M.; Klassen, J. Can they make it on their own? Hosts, microbes, and the holobiont niche. Front. Microbiol. 2016, 7, 1647. [CrossRef]

181. Ley, R.E.; Turnbaugh, P.J.; Klein, S.; Gordon, J.I. Microbial ecology: Human gut microbes associated with obesity. Nature 2006, 444, 1022-1023. [CrossRef]

182. Checcucci, A.; Maida, I.; Bacci, G.; Ninno, C.; Bilia, A.R.; Biffi, S.; Firenzuoli, F.; Flamini, G.; Fani, R.; Mengoni, A. Is the plant-associated microbiota of Thymus spp. adapted to plant essential oil? Res. Microbiol. 2017, 168, 276-282. [CrossRef]

183. Song, S.J.; Lauber, C.; Costello, E.K.; Lozupone, C.A.; Humphrey, G.; Berg-Lyons, D.; Caporaso, J.G.; Knights, D.; Clemente, J.C.; Nakielny, S.; et al. Cohabiting family members share microbiota with one another and with their dogs. eLife 2013, 2, e00458. [CrossRef]

184. Misic, A.M.; Davis, M.F.; Tyldsley, A.S.; Hodkinson, B.H.; Tolomeo, P.; Hu, B.; Nachamkin, I.; Lautenbach, E.; Morris, D.O.; Grice, E.A. The shared microbiota of humans and companion animals as evaluated from Staphylococcus carriage sites. Microbiome 2015, 3, 2. [CrossRef] 
185. Foster, K.R.; Schluter, J.; Coyte, K.Z.; Rakoff-Nahoum, S. The evolution of the host microbiome as an ecosystem on a leash. Nature 2017, 548, 43-51. [CrossRef]

186. Stencel, A.; Wloch-Salamon, D.M. Some theoretical insights into the hologenome theory of evolution and the role of microbes in speciation. Theory Biosci. 2018, 137, 197-206. [CrossRef]

187. Ivanov, I.I.; de Llanos Frutos, R.; Manel, N.; Yoshinaga, K.; Rifkin, D.B.; Sartor, R.B.; Finlay, B.B.; Littman, D.R. Specific microbiota directs the differentiation of IL-17-producing T-helper cells in the mucosa of the small intestine. Cell Host Microbe 2008, 4, 337-349. [CrossRef]

188. Chandler, J.A.; Lang, J.M.; Bhatnagar, S.; Eisen, J.A.; Artyom, K. Bacterial communities of diverse Drosophila species: Ecological context of a host-microbe model system. PLoS Genet. 2011, 7, e1002272. [CrossRef]

189. Wong, A.C.; Chaston, J.M.; Douglas, A.E. The inconstant gut microbiota of Drosophila species revealed by $16 \mathrm{~S}$ rRNA gene analysis. ISME J. 2013, 7, 1922-1932. [CrossRef]

190. McCafferty, J.; Mühlbauer, M.; Gharaibeh, R.Z.; Arthur, J.C.; Perez-Chanona, E.; Sha, W.; Jobin, C.; Fodor, A.A. Stochastic changes over time and not founder effects drive cage effects in microbial community assembly in a mouse model. ISME J. 2013, 7 , 2116-2125. [CrossRef] [PubMed]

191. Thomas, T.; Moitinho-Silva, L.; Lurgi, M.; Björk, J.R.; Easson, C.; Astudillo-García, C.; Olson, J.B.; Erwin, P.M.; Lopez-Legentil, S.; Luter, H.; et al. Diversity, structure and convergent evolution of the global sponge microbiome. Nat. Commun. 2016, 7, 11870. [CrossRef]

192. Fukami, T. Historical contingency in community assembly: Integrating niches, species pools, and priority effects. Annu. Rev. Ecol. Evol. Syst. 2015, 46, 1-23. [CrossRef]

193. Ramos, C.; Calus, M.; Schokker, D. Persistence of functional microbiota composition across generations. Sci. Rep. 2021, 11, 19007. [CrossRef] [PubMed]

194. McFall-Ngai, M.J. The importance of microbes in animal development: Lessons from the squid-vibrio symbiosis. Annu. Rev. Microbiol. 2014, 68, 177-194. [CrossRef] [PubMed]

195. Mandel, M.J.; Dunn, A.K. Impact and influence of the natural Vibrio-squid symbiosis in understanding bacterial-animal interactions. Front. Microbiol. 2016, 7, 1982. [CrossRef] [PubMed]

196. Tadych, M.; Bergen, M.S.; White, J.F. Epichloë spp. associated with grasses: New insights on life cycles, dissemination and evolution. Mycologia 2014, 106, 181-201. [CrossRef]

197. Kikuchi, Y.; Hosokawa, T.; Fukatsu, T. Insect-Microbe Mutualism without Vertical Transmission: A Stinkbug Acquires a Ben-eficial Gut Symbiont from the Environment Every Generation. Am. Soc. Microbiol. 2007, 73, 4308-4316. [CrossRef]

198. Li, Q.; Fan, J.; Sun, J.; Wang, M.-Q.; Chen, J. Plant-mediated horizontal transmission of Hamiltonella defensa in the wheat aphid Sitobion miscanthi. J. Agric. Food Chem. 2018, 66, 13367-13377. [CrossRef]

199. Brown, J.J.; Mihaljevic, J.R.; Marteaux, L.D.; Hrček, J. Metacommunity theory for transmission of heritable symbionts within insect communities. Ecol. Evol. 2019, 10, 1703-1721. [CrossRef] [PubMed]

200. Kaech, H.; Vorburger, C. Horizontal transmission of the heritable protective endosymbiont Hamiltonella defensa depends on titre and haplotype. Front. Microbiol. 2021, 11, 628755. [CrossRef]

201. Essock-Burns, T.; Bongrand, C.; Goldman, T.; Ruby, E.G.; McFall-Ngai, M.J. Interactions of symbiotic partners drive the development of a complex biogeography in the Squid-Vibrio symbiosis. mBio 2020, 11, e00853-20. [CrossRef]

202. Bright, M.; Bulgheresi, S. A complex journey: Transmission of microbial symbionts. Nat. Rev. Microbiol. 2010, 8, 218-230. [CrossRef] [PubMed]

203. Alegbeleye, O.O.; Singleton, I.; Sant'Ana, A.S. Sources and contamination routes of microbial pathogens to fresh produce during field cultivation: A review. Food Microbiol. 2018, 73, 177-208. [CrossRef]

204. Fu, H.; Zhang, L.; Fan, C.; Li, W.; Liu, C.; Zhang, H.; Cheng, Q.; Zhang, Y. Sympatric yaks and plateau pikas promote microbial diversity and similarity by the mutual utilization of gut microbiota. Microorganisms 2021, 9, 1890. [CrossRef]

205. Speakman, J.R.; Chi, Q.; Ołdakowski, Ł.; Fu, H.; Fletcher, Q.E.; Hambly, C.; Togo, J.; Liu, X.; Piertney, S.B.; Wang, X.; et al Surviving winter on the Qinghai-Tibetan Plateau: Pikas suppress energy demands and exploit yak feces to survive winter. Proc. Natl. Acad. Sci. USA 2021, 118, e2100707118. [CrossRef]

206. Liu, Y.; Fan, J.; Shi, Z.; Yang, X.; Harris, W. Relationships between plateau pika (Ochotona curzoniae) densities and biomass and biodiversity indices of alpine meadow steppe on the Qinghai-Tibet Plateau China. Ecol. Eng. 2017, 102, 509-518. [CrossRef]

207. Dill-McFarland, K.A.; Tang, Z.Z.; Kemis, J.H.; Kerby, R.L.; Chen, G.; Palloni, A.; Sorenson, T.; Rey, F.E.; Herd, P. Close social rela-tionships correlate with human gut microbiota composition. Sci. Rep. 2019, 9, 703. [CrossRef]

208. Moeller, A.H.; Foerster, S.; Wilson, M.L.; Pusey, A.E.; Hahn, B.H.; Ochman, H. Social behavior shapes the chimpanzee panmicrobiome. Sci. Adv. 2016, 2, e1500997. [CrossRef]

209. Tung, J.; Barreiro, L.B.; Burns, M.B.; Grenier, J.-C.; Lynch, J.; Grieneisen, L.E.; Altmann, J.; Alberts, S.C.; Blekhman, R.; Archie, E.A. Social networks predict gut microbiome composition in wild baboons. eLife 2015, 4, e05224. [CrossRef]

210. Gogarten, J.F.; Davies, T.J.; Benjamino, J.; Gogarten, J.P.; Graf, L.; Mielke, A.; Mundry, R.; Nelson, M.C.; Wittig, R.M.; Leendertz, F.H.; et al. Factors influencing bacterial microbiome composition in a wild non-human primate community in Taï National Park, Côte d'Ivoire. ISME J. 2018, 12, 2559-2574. [CrossRef]

211. Teyssier, A.; Lens, L.; Matthysen, E.; White, J. Dynamics of gut microbiota diversity during the early development of an avian host: Evidence from a cross-foster experiment. Front. Microbiol. 2018, 9, 1524. [CrossRef] 
212. Llewellyn, M.S.; Boutin, S.; Hoseinifar, S.H.; Nicolas Derome, N. Teleost microbiomes: The state of the art in their characterization, manipulation and importance in aquaculture and fisheries. Front. Microbiol. 2014, 5, 17. [CrossRef]

213. Sylvain, F.; Derome, N. Vertically and horizontally transmitted microbial symbionts shape the gut microbiota ontogenesis of a skin-mucus feeding discus fish progeny. Sci. Rep. 2017, 7, 5263. [CrossRef]

214. Chrostek, E.; Pelz-Stelinski, K.; Hurst, G.D.D.; Hughes, G.L. Horizontal transmission of intracellular insect symbionts via plants. Front. Microbiol. 2017, 8, 2237. [CrossRef] [PubMed]

215. Sun, Y.; Snow, D.; Walia, H.; Li, X. Transmission routes of the microbiome and resistome from manure to soil and lettuce. Environ. Sci. Technol. 2021, 55, 11102-11112. [CrossRef] [PubMed]

216. Zhang, Y.J.; Hu, H.W.; Chen, Q.L.; Singh, B.K.; Hui, Y.; He, J.Z. Transfer of antibiotic resistance from manure-amended soils to vegetable microbiomes. Environ. Int. 2019, 130, 104912. [CrossRef]

217. Roughgarden, J. Holobiont evolution: Mathematical model with vertical vs. horizontal microbiome transmission. Philos. Theory Pract. Biol. 2020, 12, 2475-3025. [CrossRef]

218. O'Brien, P.A.; Webster, N.S.; Miller, D.J.; Bourne, D.G. Host-microbe coevolution: Applying evidence from model systems to complex marine invertebrate holobionts. mBio 2019, 10, e02241-18. [CrossRef]

219. Thacker, R.W.; Freeman, C.J. Sponge-microbe symbioses: Recent advances and new directions. Adv. Mar. Biol. 2012, 62, 57-111. [PubMed]

220. de Oliveira, B.F.D.; Freitas-Silva, J.; Sánchez-Robinet, C.; Laport, M.S. Transmission of the sponge microbiome: Moving towards a unified model. Env. Microbiol. Rep. 2020, 12, 619-638. [CrossRef] [PubMed]

221. Zilber-Rosenberg, I.; Rosenberg, E. Microbial-driven genetic variation in holobionts. FEMS Microbiol. Rev. 2021,45, fuab022. [CrossRef] [PubMed]

222. Arce, A.N.; Johnston, P.R.; Smiseth, P.T.; Rozen, D.E. Mechanisms and fitness effects of antibacterial defences in a carrion beetle. J. Evol. Biol. 2012, 25, 930-937. [CrossRef] [PubMed]

223. Mushegian, A.A.; Arbore, R.; Walser, J.C.; Ebert, D. Environmental sources of bacteria and genetic variation in behavior influence host-associated microbiota. Appl. Environ. Microbiol. 2019, 85, e01547-18. [CrossRef]

224. Zheng, D.; Liwinski, T.; Elinav, E. Interaction between microbiota and immunity in health and disease. Cell Res. 2020, 30, 492-506. [CrossRef]

225. Ebert, D. The epidemiology and evolution of symbionts with mixed-m transmission. Annu. Rev. Evol. Syst. 2013, 44,623-643. [CrossRef]

226. Russell, S.L. Transmission mode is associated with environment type and taxa across bacteria-eukaryote symbioses: A systematic review and meta-analysis. FEMS Microbiol. Lett. 2019, 366, fnz013. [CrossRef]

227. Russell, S.L.; Pepper-Tunick, E.; Svedberg, J.; Byrne, A.; Ruelas, C.J.; Vollmers, C.; Beinart, R.A.; Corbett-Detig, R. Horizontal transmission and recombination maintain forever young bacterial symbiont genomes. PLoS Genet. 2020, 16, e1008935. [CrossRef] [PubMed]

228. Szafranski, K.M.; Gaudron, S.M.; Duperron, S. Direct evidence for maternal inheritance of bacterial symbionts in small deep-sea clams (Bivalvia: Vesicomyidae). Naturwissenschaften 2014, 101, 373-383. [CrossRef]

229. Bernasconi, R.; Stat, M.; Koenders, A.; Paparini, A.; Bunce, M.; Huggett, M.J. Establishment of coral-bacteria symbiosis reveal changes in core bacterial community with host ontogeny. Front. Microbiol. 2019, 10, 1529. [CrossRef]

230. Picazo, R.D.; Dagan, T.; Ansorge, R.; Petersen, J.M.; Dubilier, N.; Kupczok, A. Horizontally transmitted symbiont populations in deep-sea mussels are genetically isolated. ISME J. 2019, 13, 2954-2968. [CrossRef] [PubMed]

231. Wernegreen, J.J. Endosymbiont evolution: Predictions from theory and surprises from genomes: Endosymbiont genome evolution. Ann. N. Y. Acad. Sci. 2015, 1360, 16-35. [CrossRef]

232. Vega, N.M.; Gore, J. Stochastic assembly produces heterogeneous communities in the Caenorhabditis elegans intestine. PLoS Biol. 2017, 15, e2000633. [CrossRef] [PubMed]

233. Sasson, G.; Kruger Ben-Shabat, S.; Seroussi, E.; Doron-Faigenboim, A.; Shterzer, N.; Yaacoby, S.; Miller, M.E.B.; White, B.A.; Halperin, E.; Mizrahi, I. Heritable bovine rumen bacteria are phylogenetically related and correlated with the cow's capacity to harvest energy from its feed. mBio 2017, 8, e00703-17. [CrossRef]

234. Wang, L.; Zhang, K.; Zhang, C. Dynamics and stabilization of the rumen microbiome in yearling Tibetan sheep. Sci. Rep. 2019, 9 , 19620. [CrossRef]

235. Chen, B.; Teh, B.-S.; Sun, C.; Hu, S.; Lu, X.; Boland, W.; Shao, Y. Biodiversity and activity of the gut microbiota across the life history of the insect herbivore Spodoptera littoralis. Sci. Rep. 2016, 6, 29505. [CrossRef]

236. Turnbaugh, P.J.; Ley, R.E.; Hamady, M.; Fraser-Liggett, C.M.; Knight, R.; Gordon, J.I. The human microbiome project. Nature 2007, 449, 804. [CrossRef]

237. Hamady, M.; Knight, R. Microbial community profiling for human microbiome projects: Tools, techniques, and challenges. Genome Res. 2009, 19, 1141-1152. [CrossRef]

238. Shapira, M. Gut microbiotas and host evolution: Scaling up symbiosis. Trends Ecol. Evol. 2016, 31, 539-549. [CrossRef]

239. Li, K.; Bihan, M.; Methé, B.A. Analyses of the stability and core taxonomic memberships of the human microbiome. PLoS ONE 2013, 8, e63139. [CrossRef]

240. Risely, A. Applying the core microbiome to understand host-microbe systems. J. Anim. Ecol. 2020, 89, 1549-1558. [CrossRef] 
241. Jousset, A.; Bienhold, C.; Chatzinotas, A.; Gallien, L.; Gobet, A.; Kurm, V.; Küsel, K.; Rillig, M.C.; Rivett, D.W.; Salles, J.F.; et al. Where less may be more: How the rare biosphere pulls ecosystems strings. ISME J. 2017, 11, 853-862. [CrossRef]

242. Buschart, S.; Wilmes, P. Human gut microbiome: Function matters. Trends Microbiol. 2018, 26, 563-574. [CrossRef] [PubMed]

243. Compant, A.; Samad, A.; Faist, H.; Sessitsch, A. A review on the plant microbiome: Ecology, functions, and emerging trends in microbial application. J. Adv. Res. 2019, 19, 29-37. [CrossRef]

244. Taxis, T.; Wolff, S.; Gregg, S.J.; Minton, N.O.; Zhang, C.; Dai, J.; Schnabel, R.D.; Taylor, J.F.; Kerley, S.; Pires, J.C.; et al. The players may change but the game remains: Network analyses of ruminal microbiomes suggest taxonomic differences mask functional similarity. Nucl. Acids Res. 2015, 42, 9600-9612. [CrossRef] [PubMed]

245. Doolittle, W.F.; Booth, A. It's the song, not the singer: An exploration of holobiosis and evolutionary theory. Biol. Philos. 2017, 32, 5-24. [CrossRef]

246. Wemheuer, F.; Taylor, J.A.; Daniel, R.; Johnston, E.; Meinicke, P.; Thomas, T.; Wemheuer, B. Tax4Fun2: Prediction of habitat-specific functional profiles and functional redundancy based on 16S rRNA gene sequences. Environ. Microbiol. 2020, 15, 11. [CrossRef]

247. Tian, L.; Wang, X.W.; Wu, A.K.; Fan, Y.; Friedman, J.; Dahlin, A.; Waldor, M.K.; Weinstock, G.M.; Weiss, S.T.; Liu, Y.-Y. Deciphering functional redundancy in the human microbiome. Nat. Commun. 2020, 11, 6217. [CrossRef] [PubMed]

248. Suárez, J. The stability of traits conception of the hologenome: An evolutionary account of holobiont individuality. Hist. Philos. Life Sci. 2020, 42, 11. [CrossRef] [PubMed]

249. Yen, S.; Johnson, J.S. Metagenomics: A path to understanding the gut microbiome. Mamm. Genome 2021, 32, 282-296. [CrossRef] [PubMed]

250. Cani, P.D. Human gut microbiome: Hopes, threats and promises. Gut 2018, 67, 1716-1725. [CrossRef]

251. Poussin, C.; Boue, S.; Scotti, E.; Battey, J.; Scotti, E.; Belcastro, V.; Peitsch, M.C.; Ivanov, N.V.; Hoeng, J. Interrogating the microbiome: Experimental and computational considerations in support of study reproducibility. Drug Discov. Today 2018, 23, 1644-1657. [CrossRef] [PubMed]

252. Schloss, P.D. Identifying and overcoming threats to reproducibility, replicability, robustness, and generalizability in microbiome research. mBio 2018, 9, e00525-18. [CrossRef]

253. Fricker, A.M.; Podlesny, D.; Frick, F. What is new and relevant for sequencing-based microbiome research? A mini-review. J. Adv. Res. 2019, 19, 105-112. [CrossRef]

254. Gotschlich, E.C.; Colbert, R.A.; Gill, T. Methods in microbiome research: Past, present, and future. Best Pract. Res. Clin. Rheumatol. 2020, 33, 101498. [CrossRef]

255. Schloss, P.D.; Handelsman, J. Introducing DOTUR, a computer program for defining operational taxonomic units and estimating species richness. Appl. Environ. Microbiol. 2005, 71, 1501. [CrossRef]

256. Janda, J.M.; Abbott, S.L. 16S rRNA gene sequencing for bacterial identification in the diagnostic laboratory: Pluses, perils, and pitfalls. J. Clin. Microbiol. 2007, 45, 2761-2764. [CrossRef] [PubMed]

257. Edgar, R. Updating the 97\% identity threshold for 16 S ribosomal RNA OTUs. Bioinformatics 2018, 34, 2371-2375. [CrossRef] [PubMed]

258. Johnson, J.S.; Spakowicz, D.J.; Hong, B.Y.; Petersen, L.M.; Demkowicz, P.; Chen, L.; Leopold, R.; Hanson, B.M.; Agresta, H.O.; Gerstein, M.; et al. Evaluation of 16S rRNA gene sequencing for species and strain-level microbiome analysis. Nat. Commun. 2019, 10, 5029. [CrossRef] [PubMed]

259. Schmid, M.; Muri, J.; Melidis, D.; Varadarajan, A.R.; Somerville, V.; Wicki, A.; Moser, A.; Bourqui, M.; Wenzel, C.; Eugster-Meier, E.; et al. Comparative genomics of completely sequenced Lactobacillus helveticus genomes provides insights into strain-specific genes and resolves metagenomics data down to the strain level. Front. Microbiol. 2018, 9, 63. [CrossRef]

260. Hernández, I.; Sant, C.; Martínez, R.; Fernández, C. Design of bacterial strain-specific qPCR assays using NGS data and publicly available resources and its application to track biocontrol strains. Front. Microbiol. 2020, 11, 208. [CrossRef]

261. Roach, D.J.; Burton, J.N.; Lee, C.; Stackhouse, B.; Butler-Wu, S.M. A year of infection in the intensive care unit: Prospective whole genome sequencing of bacterial clinical isolates reveals cryptic transmissions and novel microbiota. PLoS Genet. 2017, 13, e1006724. [CrossRef]

262. Glassing, A.; Dowd, S.E.; Galandiuket, S.; Davis, B.; Chiodini, R.J. Inherent bacterial DNA contamination of extraction and sequencing reagents may affect interpretation of microbiota in low bacterial biomass samples. Gut Pathog. 2016, 8, 24. [CrossRef]

263. Stinson, L.F.; Keelan, J.A.; Payne, M.S. Identification and removal of contaminating microbial DNA from PCR reagents: Impact on low-biomass microbiome analyses. Lett. Appl. Microbiol. 2019, 68, 2-8. [CrossRef]

264. Maqsood, R.; Rodgers, R.; Rodriguez, C.; Handley, S.A.; Ndao, I.M.; Tarr, P.I.; Warner, B.B.; Lim, E.S.; Holtz, L.R. Discordant transmission of bacteria and viruses from mothers to babies at birth. Microbiome 2019, 7, 156. [CrossRef] [PubMed]

265. Bedarf, J.R.; Beraza, N.; Khazneh, H.; Özkurt, E.; Baker, D.; Borger, V.; Wüllner, U.; Hildebrand, F. Much ado about nothing? Off-target amplification can lead to false-positive bacterial brain microbiome detection in healthy and Parkinson's disease individuals. Microbiome 2021, 9, 75. [CrossRef]

266. Martinson, J.N.V.; Pinkham, N.V.; Peters, G.W.; Cho, H.; Heng, J.; Rauch, M.; Broadaway, S.C.; Walk, S.T. Rethinking gut microbiome residency and the Enterobacteriaceae in healthy human adults. ISME J. 2019, 13, 2306-2318. [CrossRef] [PubMed]

267. Louca, S.; Mazel, F.; Doebeli, M.; Parfrey, L.W. A census-based estimate of Earth's bacterial and archaeal diversity. PLoS Biol. 2019, 17, e3000106. [CrossRef] [PubMed] 
268. Walker, A.W.; Duncan, S.H.; Louis, P.; Flint, H.J. Phylogeny, culturing, and metagenomics of the human gut microbiota. Trends Microbiol. 2014, 22, 267-274. [CrossRef] [PubMed]

269. Tiede, J.; Keller, A.; Eitzinger, B. DNA sequence-based biodiversity and interaction ecology. Basic Appl. Ecol. 2021, 56, 460-463. [CrossRef]

270. Peterson, D.; Bonham, K.S.; Rowland, S.; Pattanayak, C.W.; Klepac-Ceraj, V. Comparative analysis of 16S rRNA gene and metagenome sequencing in pediatric gut microbiomes. Front. Microbiol. 2021, 12, 670336. [CrossRef]

271. Browne, H.; Forster, S.; Anonye, B.; Kumar, N.; Neville, B.A.; Stares, M.D.; Goulding, D.; Lawley, T.D. Culturing of 'unculturable' human microbiota reveals novel taxa and extensive sporulation. Nature 2016, 533, 543-546. [CrossRef]

272. Egan, M.; Dempsey, E.; Ryan, C.A.; Ross, P.; Stanton, C. The sporobiota of the human gut. Gut Microbes 2021, 13, 1. [CrossRef]

273. Von Mering, C.; Hugenholtz, P.; Raes, J.; Tringe, S.G.; Doerks, T.; Jensen, L.J.; Ward, N.; Bork, P. Quantitative phylogenetic assessment of microbial communities in diverse environments. Science 2007, 315, 1126-1130. [CrossRef]

274. Filippidou, S.; Junier, T.; Wunderlin, T.; Lo, C.-C.; Li, P.-E.; Chain, P.S.; Junier, P. Under-detection of endospore-forming Firmicutes in metagenomic data Comput. Struct. Biotechnol. J. 2015, 13, 299-306.

275. Robinson, C.D.; Bohannan, B.J.M.; Britton, R.A. Scales of persistence: Transmission and the microbiome. Curr. Opin. Microbiol. 2019, 50, 42-49. [CrossRef]

276. Yassour, M.; Jason, E.; Hogstromet, L.; Arthur, T.D.; Tripathi, S.; Siljander, H.; Selvenius, J.; Oikarinen, S.; Hyöty, H.; Virtanen, S.M.; et al. Strain-level analysis of mother-to-child bacterial transmission during the first few months of life. Cell Host Microbe 2018, 24, 146-154. [CrossRef]

277. Palmer, C.; Bik, E.M.; DiGiulio, D.B.; Relman, D.A.; Patrick, O.; Brown, P.O. Development of the human infant intestinal microbiota. PLoS Biol. 2007, 5, e177. [CrossRef] [PubMed]

278. Tiihonen, K.; Ouwehand, A.C.; Rautonen, N. Human intestinal microbiota and healthy ageing. Ageing Res. Rev. 2010, 9, 107-116. [CrossRef] [PubMed]

279. Radjabzadeh, D.; Boer, C.G.; Beth, S.A.; van der Wal, P.; Kiefte-De Jong, J.C.; Jansen, M.A.E.; Konstantinov, S.R.; Peppelenbosch, M.P.; Hays, J.P.; Jaddoe, V.W.V.; et al. Diversity, compositional and functional differences between gut microbiota of children and adults. Sci. Rep. 2020, 10, 1040. [CrossRef]

280. Münger, E.; Montiel-Castro, A.J.; Langhans, W.; Pacheco-López, G. Reciprocal interactions between gut microbiota and host social behavior. Front. Integr. Neurosci. 2018, 12, 21. [CrossRef]

281. Wale, M.; Daffonchio, D.; Fusi, M.; Marasco, R.; Garuglieri, E.; Diele, K. The importance of larval stages for considering crab microbiomes as a paradigm for the evolution of terrestrialization. Front. Microbiol. 2021, 12, 770245. [CrossRef] [PubMed] 